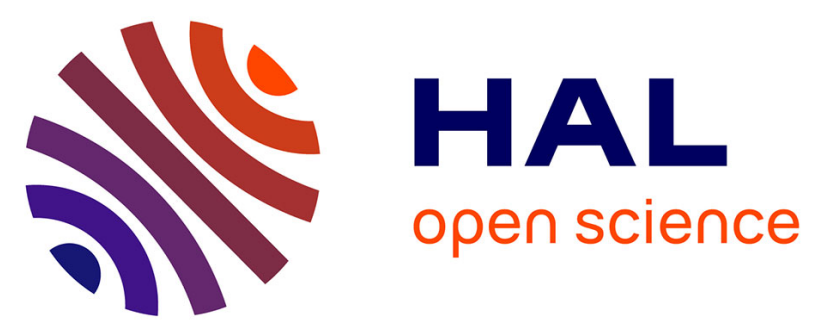

\title{
Synthesis of Sulfur-Containing Exo-Bicyclic Dienes and Their Diels-Alder Reactions to Access Thiacycle-Fused Polycyclic Systems
}

T. Castanheiro, A. Schoenfelder, M. Donnard, Isabelle Chataigner, M. Gulea

\section{- To cite this version:}

T. Castanheiro, A. Schoenfelder, M. Donnard, Isabelle Chataigner, M. Gulea. Synthesis of SulfurContaining Exo -Bicyclic Dienes and Their Diels-Alder Reactions to Access Thiacycle-Fused Polycyclic Systems. Journal of Organic Chemistry, 2018, 83 (8), pp.4505-4515. 10.1021/acs.joc.8b00213 . hal02024483

HAL Id: hal-02024483

https://hal-normandie-univ.archives-ouvertes.fr/hal-02024483

Submitted on 9 Feb 2022

HAL is a multi-disciplinary open access archive for the deposit and dissemination of scientific research documents, whether they are published or not. The documents may come from teaching and research institutions in France or abroad, or from public or private research centers.
L'archive ouverte pluridisciplinaire HAL, est destinée au dépôt et à la diffusion de documents scientifiques de niveau recherche, publiés ou non, émanant des établissements d'enseignement et de recherche français ou étrangers, des laboratoires publics ou privés. 


\title{
Synthesis of sulfur-containing exo-bicyclic dienes and their Diels- Alder reactions to access thiacycle-fused polycyclic systems
}

\author{
Thomas Castanheiro, ${ }^{\mathrm{a}}$ Angèle Schoenfelder, ${ }^{\mathrm{a}}$ Morgan Donnard, ${ }^{\mathrm{a}}$ \\ Isabelle Chataigner, ${ }^{\mathrm{b}, \mathrm{c}}$ and Mihaela Gulea ${ }^{\mathrm{a}^{*}}$
}

${ }^{a}$ Université de Strasbourg, CNRS, Laboratoire d'Innovation Thérapeutique, LIT UMR 7200, 67000 Strasbourg, France

${ }^{b}$ Normandie Université, INSA Rouen, CNRS, COBRA UMR 6014, 76000 Rouen, France

'Sorbonne Université, UPMC Univ. Paris 6, CNRS UMR 7616 Laboratoire de Chimie

Théorique, 75005 Paris, France
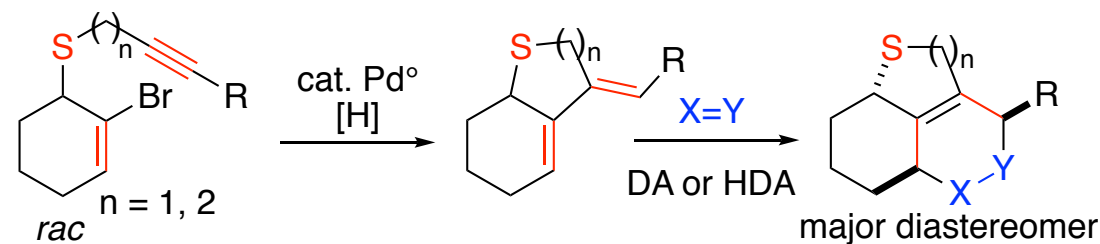

\begin{abstract}
The stereocontrolled synthesis of unprecedented sulfur-containing exo-bicyclic 1,3-dienes is reported through a palladium-catalyzed reductive cyclization of sulfur-linked 2-bromoenynes. The fused bicyclic structure provides a better stability to the thiacyclic diene, compared to the simple 3,4dimethylenetetrahydrothiophene. Their reactivity towards several dienophiles has been investigated and various original thiacycle-fused polycyclic systems have been obtained, with high or total diastereoselectivity. Moreover, they are the first exo-bicyclic dienes used in Diels-Alder reactions. The relative configurations of four cycloadducts have been unambiguously assigned by X-ray crystallographic analysis. Mechanistic details of the cycloadditions have been examined by computational means.
\end{abstract}

\section{Introduction}

Sulfur-heterocycles (often called thiacycles) are important constituents of biologically active molecules for pharmaceutical industry. ${ }^{1}$ Therefore, providing new complex structures containing a thiacycle as potential drug candidates, represents a topical research subject. 
As part of our interest in accessing various S-heterocycles, we have envisioned to access new sulfur-containing fused polycyclic systems via [4+2] cycloadditions involving exo-thiacyclic 1,3-dienes. Indeed, exo-cyclic 1,3-dienes ${ }^{2}$ are widely used partners in DielsAlder (DA) reactions, due both to their high reactivity provided by their fixed s-cis conformation, and their synthetic usefulness consisting in the direct access to fused bicyclic structures, which are often found in natural products. ${ }^{3}$ Various efficient methodologies have been developed to synthesize exo-cyclic dienes, including palladium-catalyzed ${ }^{4}$ and radical cyclizations. $^{5}$

As far as the sulfur series is concerned, exo-thiacyclic 1,3-diene I, namely the 3,4dimethylenetetrahydrothiophene (Figure 1), has been prepared by Gaoni and Sadeh from 2,3bis(bromomethy1)-1,3-butadiene and sodium sulfide, then used in a Diels-Alder reaction with dimethyl acetylenedicarboxylate (DMADC) as dienophile. ${ }^{6}$ The authors noted the instability of this diene resulting mostly in its transformation into the corresponding 3,4dimethylthiophene and its very fast polymerization in the free states. Exo-bicyclic Scontaining dienes of type II (Figure 1) should provide a better stability due to hyperconjugation effect brought by the substituents on the double bonds and the bicyclic structure. Therefore, we decided to synthesize these hitherto unknown 1,3-dienes and to investigate their reactivity in [4+2] cycloadditions. Access to these bicyclic structures bearing a stereogenic carbon center next to the sulfur atom was first envisaged in the racemic form. After cycloaddition, the thiacycle-fused polycyclic cycloadducts thereby produced should have interesting $3 \mathrm{D}$-structures, the stereochemistry of the newly formed stereogenic centers being governed both by the existing stereocenter and by the cycloaddition process itself, in line with modern concepts in drug discovery. ${ }^{7}$
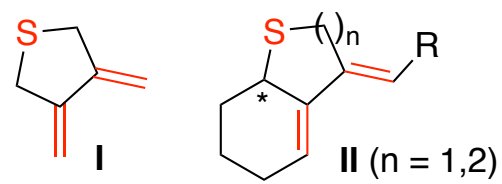

Figure 1. Known exo-thiacyclic diene I and envisaged more stable exo-bicyclic dienes II

A literature survey revealed that while exo-monocyclic dienes are abundant, exobicyclic dienes are rarely encountered. Only a few examples of these 1,3-dienes have been reported (Scheme 1): the carbo-bicyclic (Eq. 1), ${ }^{8}$ and aza-bicyclic (Eq. 2) ${ }^{9}$ dienes were obtained via an intramolecular Heck reaction, and the oxacyclic dienes were generated via radical cyclizations using $\mathrm{Bu}_{3} \mathrm{SnH} / \mathrm{AIBN}$ system or $\mathrm{SmI}_{2}$ (Eq. 3). ${ }^{10}$ These methods afforded 
the 1,3-dienes as a mixture of $E / Z$ isomers. ${ }^{11}$ Noteworthy, the reactivity in Diels-Alder reactions of these exo-bicyclic dienes has not been examined so far.

The powerful synthetic tool represented by the palladium-catalyzed domino cyclizations ${ }^{12}$ together with our experience in using sulfides as substrates for these reactions, ${ }^{13}$ prompted us to envisage 5- or 6-exo-dig syn-cyclocarbopalladation/reduction sequences to generate the sulfur containing exo-bicyclic 1,3-dienes. This process should lead to an exclusive $Z$ geometry of the generated double bond, as a result of the well established syncarbopalladation mechanism. ${ }^{4}$ We report herein the preparation of racemic dienes II and their use in Diels-Alder or hetero-Diels-Alder (HDA) reactions to access unprecedented Scontaining polycyclic compounds (Scheme 1, Eq. 4).

Carboxyclic series: Tietze et al. ${ }^{8}$<smiles>C/C=C\CCCC1CCCC=C1O</smiles>

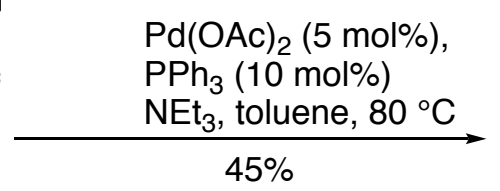<smiles>CC=C1CCCC2CCCC=C12</smiles>

(Eq. 1)

\section{E/Z mixture}

not used in DA

Azacyclic series: Grigg et al. ${ }^{9}$<smiles>C=C1CN(C(=O)O)C2C1=CC1CCC2C1[O+]</smiles><smiles>C=CCN1CCCC1</smiles>

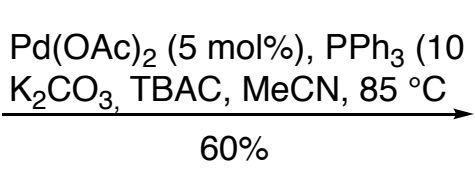
$60 \%$

Oxacyclic series: Sha, Zhan et al. ${ }^{10}$ not used in DA<smiles>PC#CCCOC1CCCC=C1I</smiles>

$\mathrm{Sml}_{2}$, THF, HMPA, rt / or $\mathrm{Bu}_{3} \mathrm{SnH} / \mathrm{AIBN}, \mathrm{C}_{6} \mathrm{H}_{6}$, reflux $20-80 \%$<smiles>CC=CC1=CCCCC1</smiles>

E/Z mixture not used in DA

Thiacyclic series: this work<smiles>[R]C#CCSC1CCCC=C1Br</smiles>

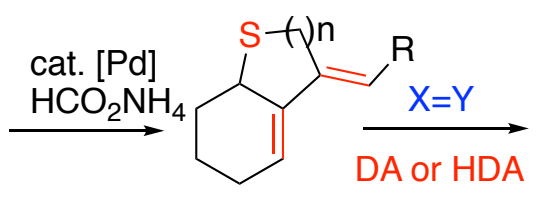<smiles>[X]C([R])C1=C2C([X])CCCC2SN1</smiles>
(Eq. 4)

Scheme 1. Syntheses of exo-bicyclic dienes 


\section{Results and discussion}

We first prepared thioacetic ester 1 from 1,6-dibromocyclohex-1-ene and potassium thioacetate, then used it as the starting material to access sulfur-linked 2-bromo-1,6- and 2bromo-1,7-enynes $\mathbf{2}$, which are the suitable precursors of the desired dienes $\mathbf{3}$ (Scheme 2).

Sulfides 2a-f have been synthesized with satisfactory yields from $\mathbf{1}$ and the corresponding propargyl or homopropargyl halide, with different R substituents on the triple bond. Sulfide $\mathbf{2 f}$ was obtained by introducing a phenyl group on the terminal alkyne of $2 \mathbf{e}$ via a Sonogashira cross-coupling. These substrates have been then reacted under Pd-catalyzed reaction conditions in the presence of ammonium formate as the hydrogen donor. ${ }^{14}$ Gratifyingly, the reductive cyclization sequence led to the desired exo-bicyclic dienes 3a-d,f in moderate to good yields. The Z-geometry of the newly formed double bond is assumed considering the syn-carbopalladation/reduction process, and no trace of another isomer of the diene was detected by NMR analysis. Once again the use of sulfur-containing compounds was compatible with the Pd-catalysis conditions. Only diene $\mathbf{3 e}(\mathrm{R}=\mathrm{H})$ was obtained in a disappointing yield ( $22 \%$ by $1 \mathrm{H} \mathrm{NMR})$ and could not be isolated in a pure form. This is probably due to competitive S-depropargylation reaction in the presence of the palladium catalyst, occurring more easily on the terminal alkynyl substrate $2 \mathbf{e}^{15}$ The method is efficient for both accessing 5- and 6-membered rings bearing either alkyl, phenyl or hydroxymethyl terminal groups. Indeed, the fused bicyclic dienes provide a better stability to these thiacyclic dienes, compared to 3,4-dimethylenetetrahydrothiophene $\mathbf{I}$, as they can be isolated by column chromatography and stored at least one week at room temperature. 

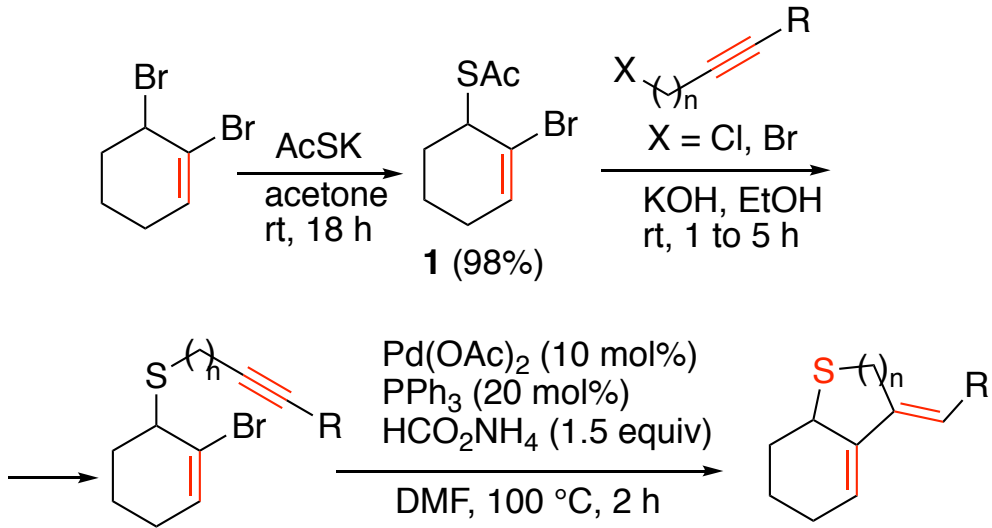
2a: $R=E t, n=1(80 \%)$
2b: $R=P h, n=1(55 \%)$
3a: $R=E t, n=1(68 \%)$
2c: $\mathrm{R}=\mathrm{CH}_{2} \mathrm{OH}, \mathrm{n}=1(89 \%)$
3b: $\mathrm{R}=\mathrm{Ph}, \mathrm{n}=1(60 \%)$
2d: $\mathrm{R}=\mathrm{Me}, \mathrm{n}=2(81 \%)$
2e: $R=H, n=2(76 \%)$
3c: $\mathrm{R}=\mathrm{CH}_{2} \mathrm{OH}, \mathrm{n}=1(46 \%)$
2f: $R=P h, n=2(84 \%)$
$3 d: R=M e, n=2(55 \%)$
3e: $\mathrm{R}=\mathrm{H}, \mathrm{n}=2$ (nd)
3f: $\mathrm{R}=\mathrm{Ph}, \mathrm{n}=2(78 \%)$

Scheme 2. Synthesis of sulfur-containing exo-bicyclic dienes 3

With these thiacyclic dienes in hands, we then envisaged their involvement in DielsAlder reactions with a range of four electron-deficient symmetrical dienophiles: maleic anhydride D1, N-phenylmaleimide D2, dimethylacetylene dicarboxylate D3, and 4-phenyl3H-1,2,4-triazole-3,5(4H)-dione D4. All products are obtained in a racemic form and their relative configurations are represented in all schemes.

First, all isolated dienes were reacted with maleic anhydride D1, in dichloromethane, at $40{ }^{\circ} \mathrm{C}$ (Scheme 3). A complete consumption of the diene was observed within 2 to 4 hours. Theoretically, the cycloaddition between diene 3 and dienophile D1 can lead to four couples of diastereomeric cycloadducts $\mathbf{4 A - D}$, arising from the four possible approaches: two from the top/bottom face of the diene and two according to the endo/exo orientations. The reaction with 3a led to a mixture of two inseparable diastereomers in 8:2 ratio (91\% yield). NMR analyses (NOEDIFF correlations) indicated that the major cycloadduct resulted from the expected endo-attack, however it was difficult to distinguish between $\mathbf{4 a A}$ and $\mathbf{4 a B}$. 

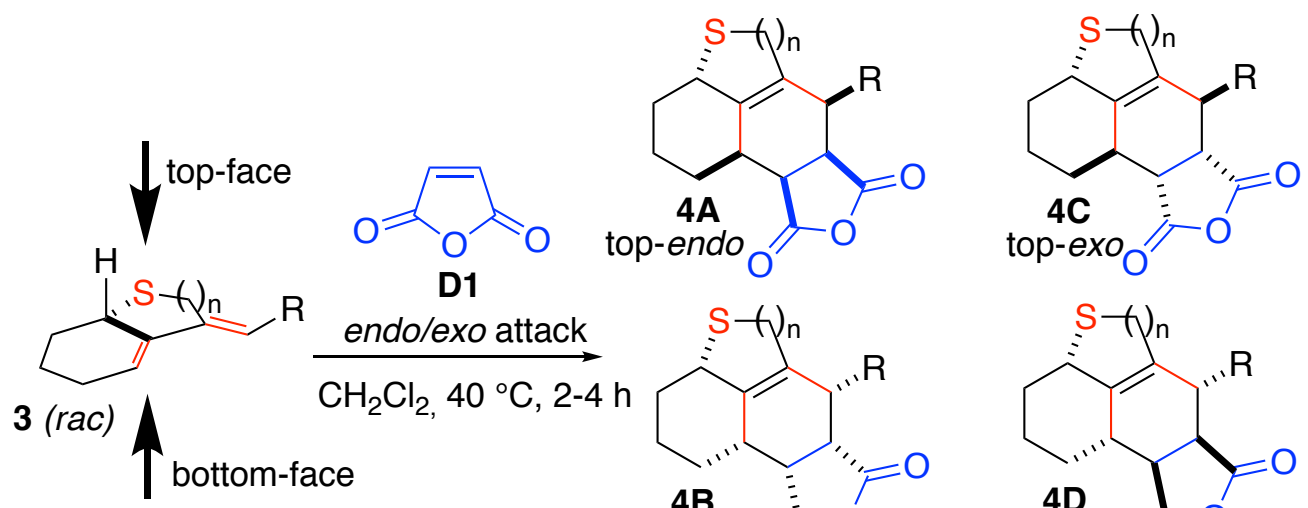

bottom-endo
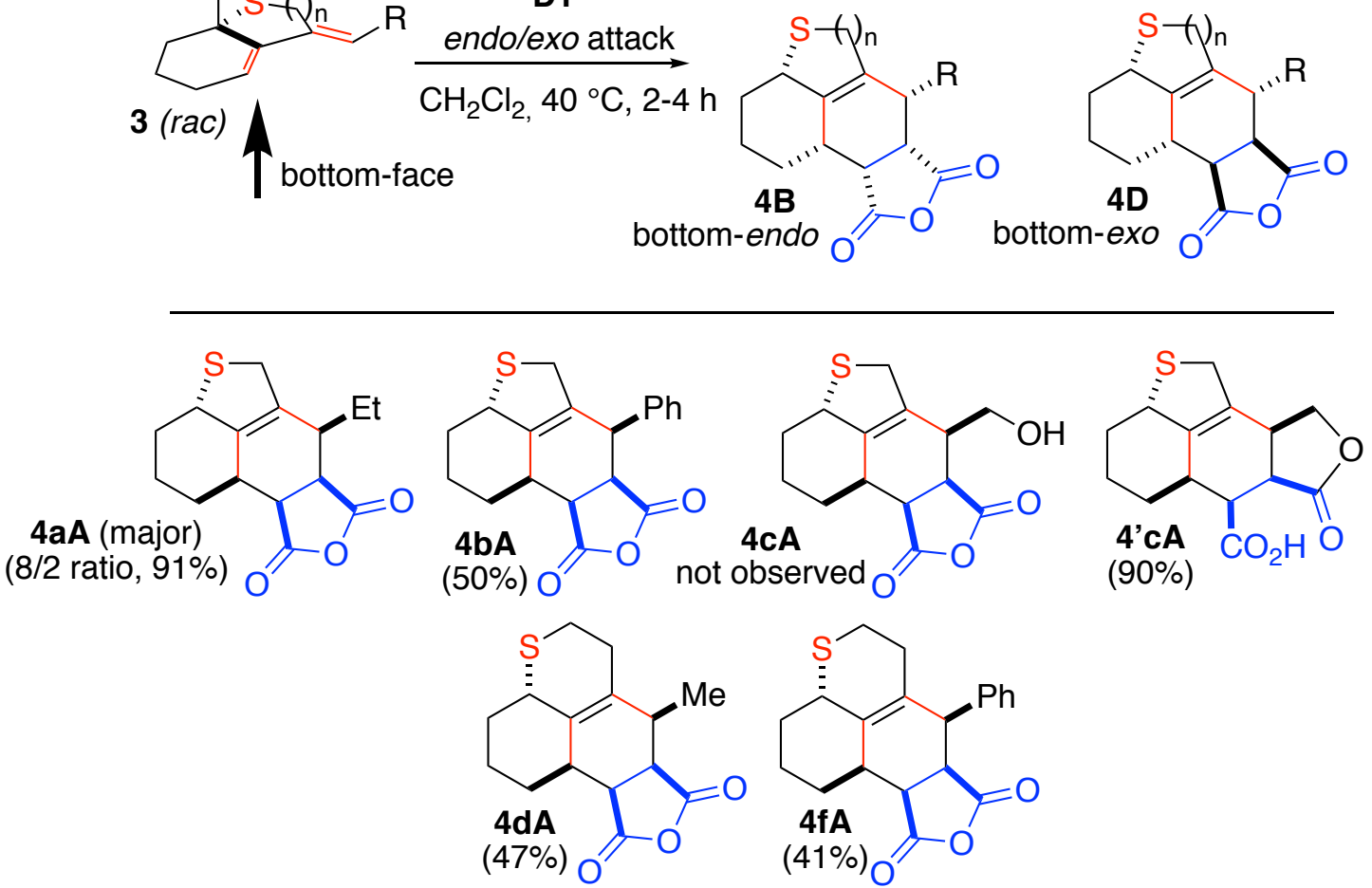

Scheme 3. Diels-Alder reactions of exo-bicyclic dienes 3 with D1 (ratio diene/D1 1.1:1)

In the case of the phenyl substituted diene $\mathbf{3 b}$, the formation of a single diastereomer was observed. The relative stereochemistry of the isolated adduct $4 \mathbf{b A}$ (50\% yield) was unambiguously assigned by an X-ray crystallographic analysis (Figure 2) and confirmed the favored endo approach from the less hindered face of the diene (top-face), opposite to the Scontaining ring. Then, in the reaction between D1 and diene 3c the product 4'cA was obtained as the only adduct in $90 \%$ yield. In this case the cycloaddition was followed by an intramolecular lactonization occurring on cycloadduct $\mathbf{4 c A}$ and leading to $\mathbf{4}^{\mathbf{\prime}} \mathbf{c} \mathbf{A} .{ }^{16} \mathrm{X}$-Ray crystallographic analysis on a monocrystal also confirmed the structure and the relative stereochemistry of the product in this case (Figure 3). The cycloaddition of D1 with the 6membered ring exo-bicyclic dienes $\mathbf{3 d}$ and $\mathbf{3 f}$ led to a single diastereomer, $4 \mathbf{d A}$ (47\% yield) and $\mathbf{4 f A}$ (41\% yield), respectively. Crystals obtained from $\mathbf{4 f \mathbf { A }}$ allowed to obtain an X-ray structure (Figure 4), which revealed that its relative stereochemistry was similar to $4 \mathrm{bA}$. The relative configurations of $\mathbf{4 a A}$ and $4 \mathbf{d A}$ were then assigned by analogy with the previous results. 


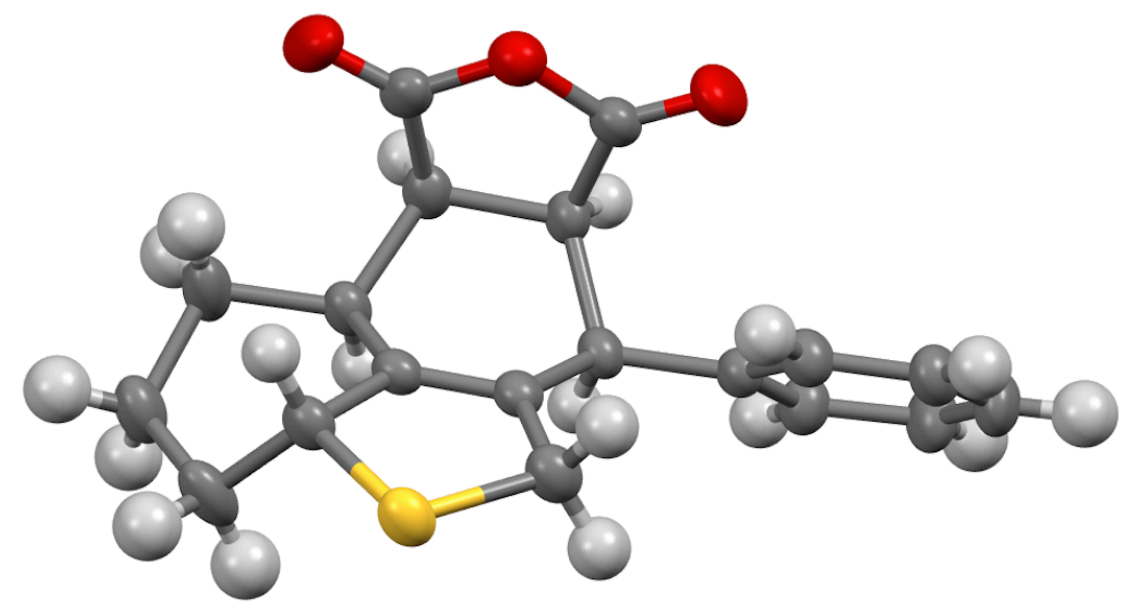

Figure 2. X-ray structure of $\mathbf{4 b A}$ (50\% probability ellipsoids)

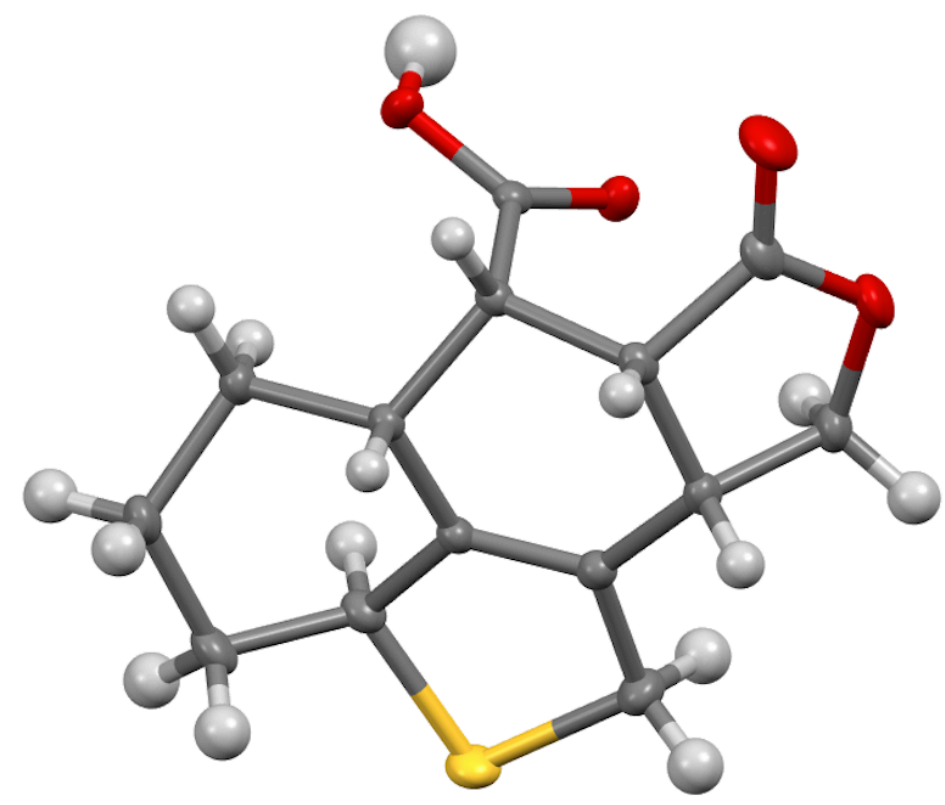

Figure 3. X-ray structure of 4'cA (50\% probability ellipsoids) 


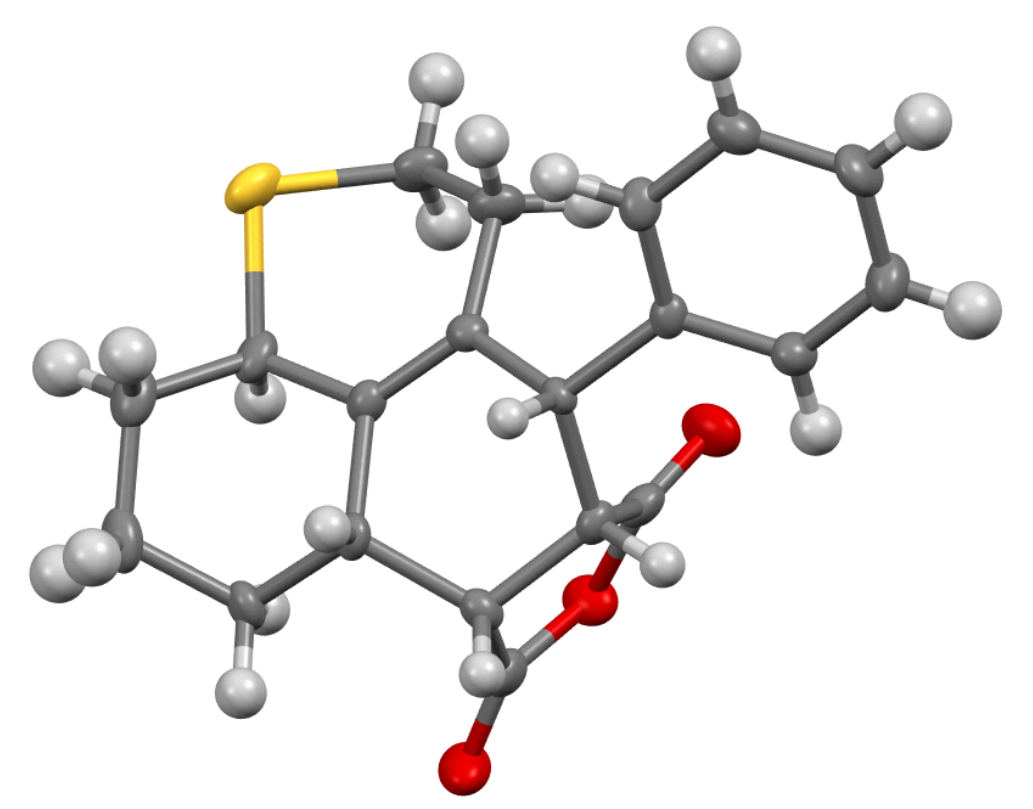

Figure 4. X-ray structure of $\mathbf{4 f A}$ (50\% probability ellipsoids)

N-Phenylmaleimide D2 was then reacted with dienes 3a and 3b under the same reaction conditions. In both cases only one diastereomer was formed and we assume that they are respectively 5aA (93\% yield) and $\mathbf{5 b A}$ (97\% yield), having the same relative configurations than those obtained with D1 (Scheme 4).

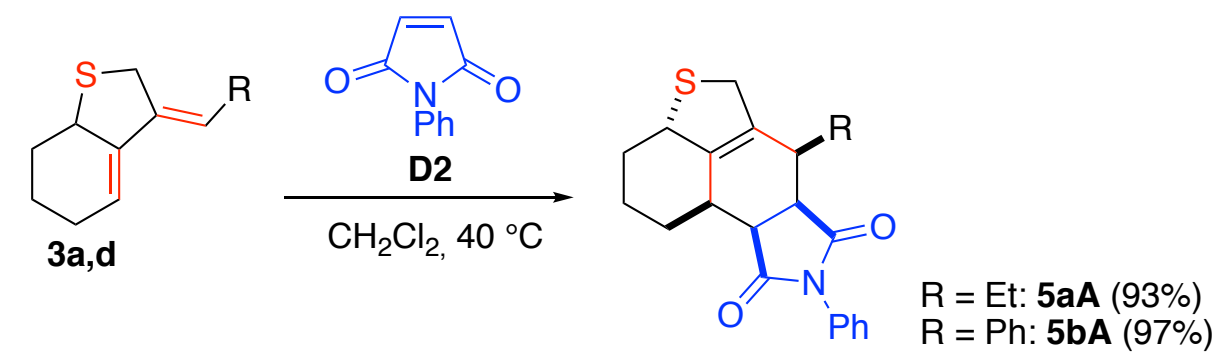

Scheme 4. Diels-Alder reactions of exo-bicyclic dienes 3a,b with D2 (ratio diene/D2 1.1:1)

Dimethylacetylene dicarboxylate D3 was then reacted with dienes $\mathbf{3 a}, \mathbf{3 b}$, and $\mathbf{3 d}$. Heating in toluene at $80{ }^{\circ} \mathrm{C}$ overnight was necessary to get completion in this case. Cycloadducts 6a and $\mathbf{6 d}$ were obtained as a mixture of two diastereomers (A/B) in 10:3 and 2:1 ratio, respectively (Scheme 5). Very probably, similarly to the previous cases, the major products are respectively $\mathbf{6 a A}$ and $\mathbf{6 d A}$, resulting from the top-face approach of the diene. The product resulting from $\mathbf{3 b}$ decomposed and could not be characterized. 


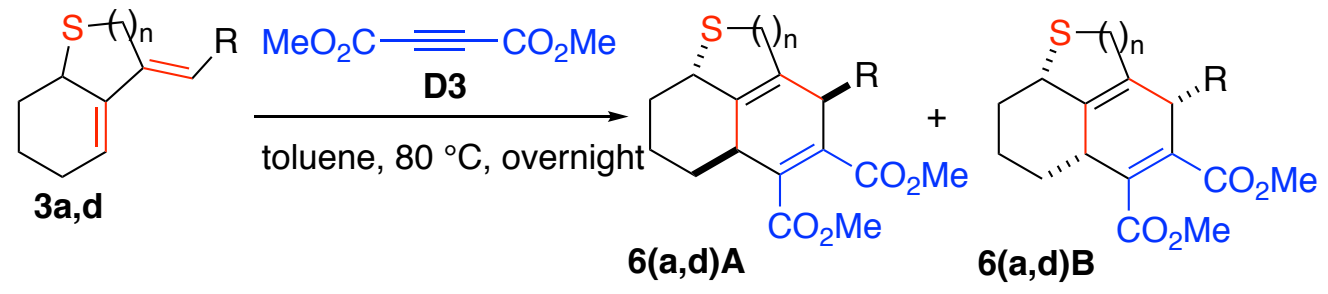

$\mathrm{R}=\mathrm{Et}, \mathrm{n}=1:$ 6aA $6 \mathrm{aB}(10 / 3$ ratio, $65 \%)$

$R=M e, n=2: 6 d A / 6 d B(2 / 1$ ratio, $54 \%)$

Scheme 5. Diels-Alder reactions of exo-bicyclic dienes 3 with D3 (ratio diene/D3 1:1.5)

Hetero-Diels-Alder (HDA) reactions have been then attempted with an aza-dienophile, the 4phenyl-3H-1,2,4-triazole-3,5(4H)-dione D4 (Scheme 6). The reactions were performed in dichloromethane, at room temperature, until complete consumption of the substrates was observed ( 0.5 to 1 hour). Both 5-membered ring dienes $\mathbf{3 a}$ and $\mathbf{3 b}$ led to a mixture of two separable products in 1:2 and 1:1 ratio, respectively. The two products derived from 3a have been identified as cycloadduct $7 \mathbf{a A}$ (22\% yield) and the corresponding thiophene derivative $\mathbf{8 a}$ ( $45 \%$ yield), formed by a dehydrogenative aromatization of the dihydrothiophene ring of the cycloadduct 7a. Dienophile D4 is probably involved in this latter transformation and further studies will be done to propose a plausible mechanism. Similarly, products $7 \mathbf{b A}$ and $\mathbf{8 b}$ resulting from diene $\mathbf{3 b}$ have been isolated in $22 \%$ and $26 \%$ yield, respectively. The structure of $8 \mathbf{b}$ was confirmed by X-ray crystallographic analysis (Figure 5). In the cases of 6membered ring exocyclic dienes, the oxidation of the thiacycle did not occurred, and only the expected cycloaddition products were obtained. The reaction between D4 and diene $\mathbf{3 d}$ led to a 20:1 mixture of diastereomers, whereas diene $\mathbf{3 f}$ led to a single diastereomer, which was isolated in 60\% yield. By adding D4 at room temperature to the crude diene 3e, the expected product was also obtained as a single diastereomer, however with a low isolated yield of $15 \%$. Assignments of the relative configurations of the major (or single) cycloadducts (7aA, $7 \mathbf{b A}$, 7dA, 7eA, 7fA) were done by analogy with the previous results, which correspond to a topface approach of the diene (Scheme 6). 
<smiles>[R]C=C1CSC2CCC[R16](c3ccccc3)C=C12</smiles>

$7(a, b) A$<smiles>[R]C1c2csc3c2C(CCC3)n2c(=O)n(-c3ccccc3)c(=O)n21</smiles>

$8 \mathrm{a}, \mathrm{b}$<smiles>[R]C1C2=C3[C@H]1CCC[C@H]3n1c(=O)n(-c3ccccc3)c(=O)n12</smiles>

7(a,b)B not observed

$\mathrm{R}=\mathrm{Et}: \mathbf{7 a A}(22 \%) ; \mathbf{8 a}(45 \%)$

$\mathrm{R}=\mathrm{Ph}: \mathbf{7 b A}(22 \%) ; \mathbf{8 b}(26 \%)$<smiles>O=c1[nH]n(-c2ccccc2)c(=O)n1-c1ccccc1</smiles><smiles>[R]C1C2=C3[C@H](CCC[C@H]31)SCC2</smiles><smiles>[R]C1C2=C3[C@H]1CCC[C@H]3SCC2</smiles>

$$
\begin{aligned}
& R=\mathrm{Me}: 7 \mathrm{dA} / 7 \mathrm{~dB} \text { (20/1 ratio, } 51 \%) \\
& \mathrm{R}=\mathrm{H}: \mathbf{7 e A}(15 \%) \\
& \mathrm{R}=\mathrm{Ph}: \mathbf{7 f A}(60 \%)
\end{aligned}
$$

Scheme 6. Hetero-Diels-Alder reactions of exo-bicyclic dienes 3 with D4 (ratio diene/D4 1:2)

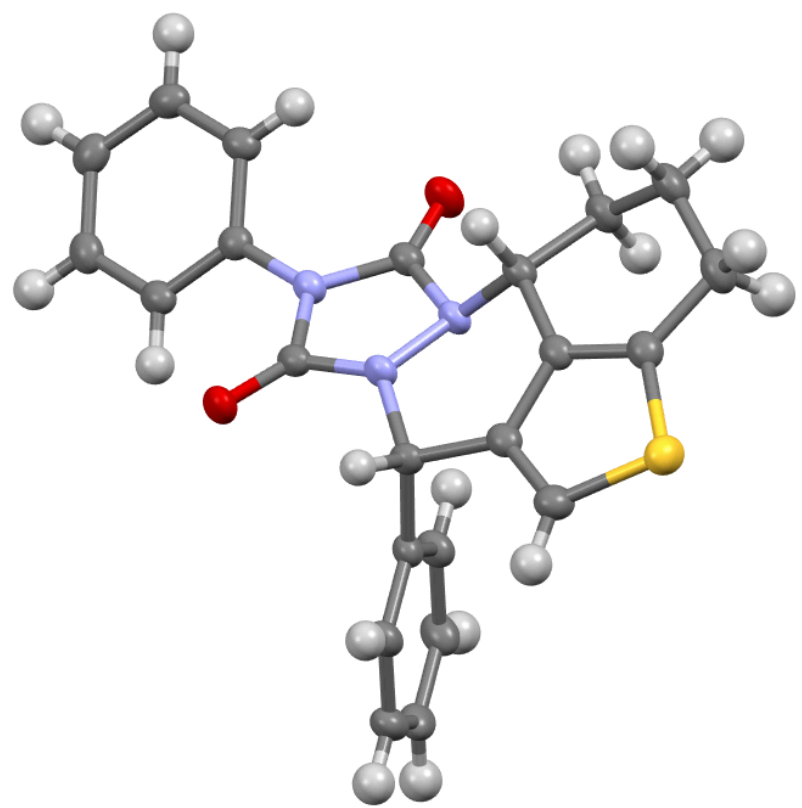

Figure 5. X-ray structure of $\mathbf{8 b}$ (50\% probability ellipsoids)

We finally explored the more challenging HDA-reaction with the dithioester heterodienophile D5, ${ }^{17}$ in order to obtain structures containing two sulfur-heterocycles 
(Scheme 7). As this dienophile is non-symmetric, two regioisomeric cycloadducts can be expected, each one with four relative stereochemistries mentioned before. The reaction was performed in dichloromethane, at room temperature, in the presence of $\mathrm{BF}_{3}$. $\mathrm{Et}_{2} \mathrm{O}$ as Lewis acid to activate the dienophile. An inseparable mixture of two products in 3:1 ratio, was obtained with diene 3a, however we were not able to determine their structures, since the products decomposed fast. The reactions of $\mathbf{D 5}$ with dienes $\mathbf{3 b}$ and $\mathbf{3 f}$ also afforded mixtures of two products in a ratio of 10:1 and 10:3, respectively. In the case of the two cycloadducts resulted from 3f, a series of NMR experiments indicate that they correspond to two diastereomers of regioisomer 10f, of which the relative configurations differ at the $\mathrm{CHS}^{1}$ carbon-stereocenter, as the result of the top/bottom approaches. It was however difficult to categorically conclude on the relative configurations at the $\mathrm{CHS}^{2}$ carbon-stereocenter (endo vs exo approach relative to pyridyl), although several NOESY-2D and selective NOESY-1D experiments match well with products 10fA (major) and 10fB (minor) having pyridyl and phenyl substituents in a cis relationship (endo approach). Geometry optimization of 10fA and $10 \mathrm{fB}$ (DFT calculations) is also in agreement with this assignment (see in Supporting Information).

The overall results showed that the stereochemical course of the Diels-Alder reaction involving exo-bicyclic dienes 3 did not depend on the tethered ring-size, as both five and sixmembered thiacyclic dienes give high selectivities. The cycloadducts resulting from fivemembered thiacyclic dienes and aza-dienophile D4 are prone to aromatization into the corresponding thiophene derivatives. Concerning the nature of the substituent on the triple bond, a phenyl substituent led to slightly better selectivity than an alkyl one. 


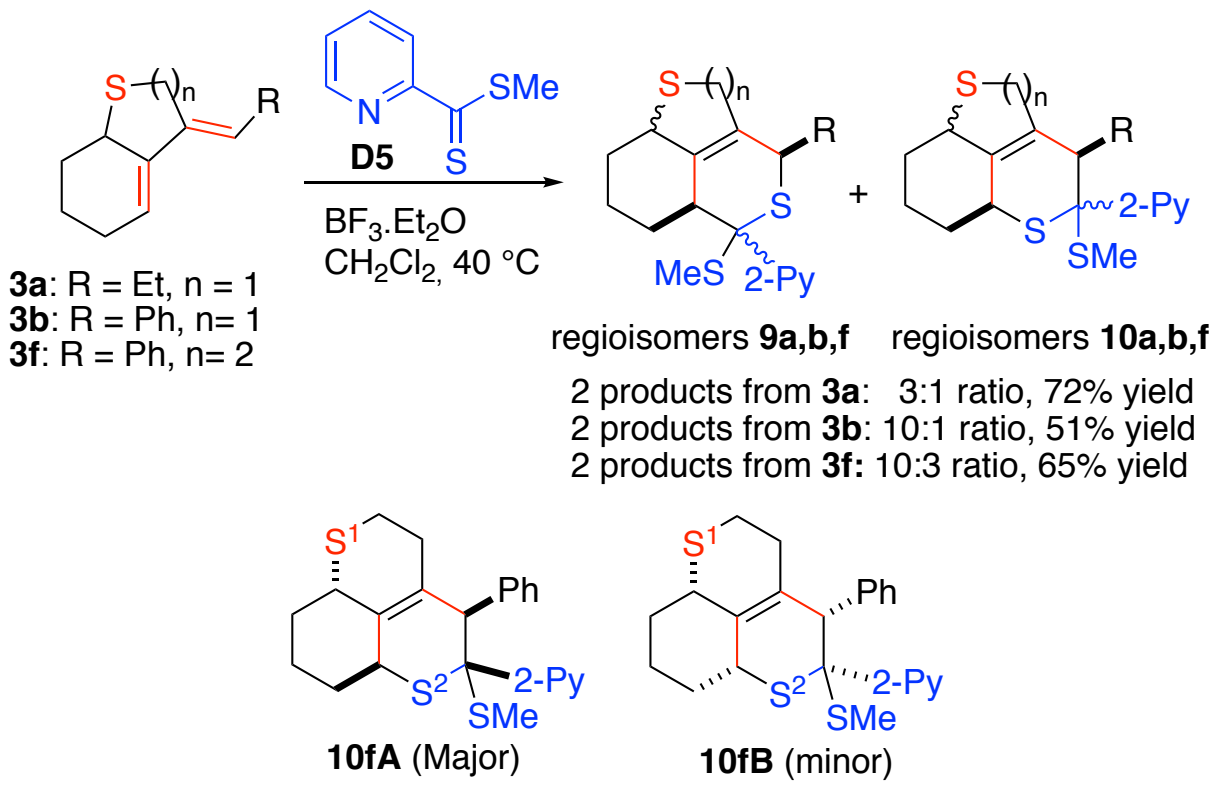

Scheme 7. thia-Diels-Alder reactions of exo-bicyclic dienes 3 (ratio diene/D5 1.1:1)

\section{Theoretical study}

In order to get a better insight into the mechanistic details of these cycloadditions, we then examined the course of the reaction by computational means. DFT calculations were performed at the $w B 97 \mathrm{XD} / 6-31+\mathrm{G}(\mathrm{d}, \mathrm{p})$ level of theory, including dispersion terms, which proved appropriate for similar organic systems ${ }^{18}$ (see SI for the results obtained with other functionals, basis sets and inclusion of solvent effects). Computations were first effected with diene 3b and maleic anhydride (D1) as dienophile. Optimization of the diene conformation expectedly showed a half-chair conformational preference for the cyclohexenyl moiety. An energy minimum was found for the conformer with a $\mathrm{C}=\mathrm{C}-\mathrm{C}=\mathrm{C}$ dihedral angle of $42.2^{\circ}$. Evaluation of the frontier orbitals energies confirmed the preferential interaction between the HOMO of diene $\mathbf{3 b}$ and the LUMO of dienophile D1, and thus the normal electron demand character of the cycloaddition process. Quantitative evaluation of the preferred pathway on the activation energy was then undertaken, by localization of the transition states (TS) of the cycloaddition. Four arrangements were considered, depending on the face approach: top/bottom approach of the dienophile and the endo/exo orientations (Figure 6). The cycloaddition proved exergonic in each case. The most favored transition states were found to be $20.57 \mathrm{kcal}^{\mathrm{mol}}{ }^{-1}$ above the reactants for the top-endo approach (A) and $23.57 \mathrm{kcal}^{\mathrm{mol}}{ }^{-1}$ for the top-exo one (C). The bottom-endo TS (B) was slightly higher in energy $(24.37 \mathrm{kcal} . \mathrm{mol}-$ 1) while the bottom-exo (D) one proved to be the least favorable $\left(27.68 \mathrm{kcal}^{\mathrm{mol}} \mathrm{m}^{-1}\right)$. 
Considering the reaction is under kinetic control, the $3.00 \mathrm{kcal}^{\mathrm{mol}} \mathrm{m}^{-1}$ difference between the two most favoured TS should thus allow for a good if not complete stereocontrol of the cycloaddition. Experimentally, the only stereoisomer formed and isolated when interacting $\mathbf{3 b}$ with D1 proved to be $\mathbf{4 b A}$. These DFT calculations are thus in line with these results since the top-endo TS indeed leads to cycloadduct $\mathbf{4 b A}$. The process appeared to be concerted and slightly asynchronous, the lengths of the forming bonds $\mathrm{CH}^{\text {cyclo }}-\mathrm{C}^{\text {dienophile }}$ and $\mathrm{CH}^{\mathrm{Ph}}-\mathrm{C}^{\text {dienophile }}$ being in the same range, $2.10 \AA$ and $2.36 \AA$, respectively for the most favored top-endo TS. The phenyl substituent of the diene moiety was not conjugated with the double bond but the dihedral angle $\mathrm{C}^{\text {diene }}=\mathrm{C}^{\text {diene }} \mathrm{H}-\mathrm{C}^{\mathrm{Ph}}=\mathrm{C}^{\mathrm{Ph}} \mathrm{H}$ was small $\left(23.95^{\circ}\right)$. All attempts to find zwitterionic intermediates were unsuccessful.

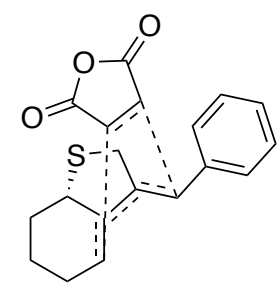

A : top-endo

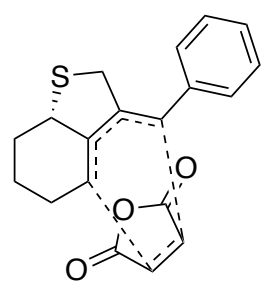

B : bottom-endo

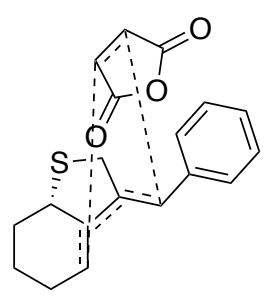

C : top-exo

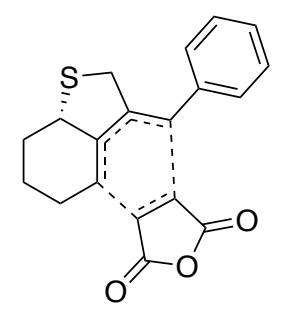

D : bottom-exo

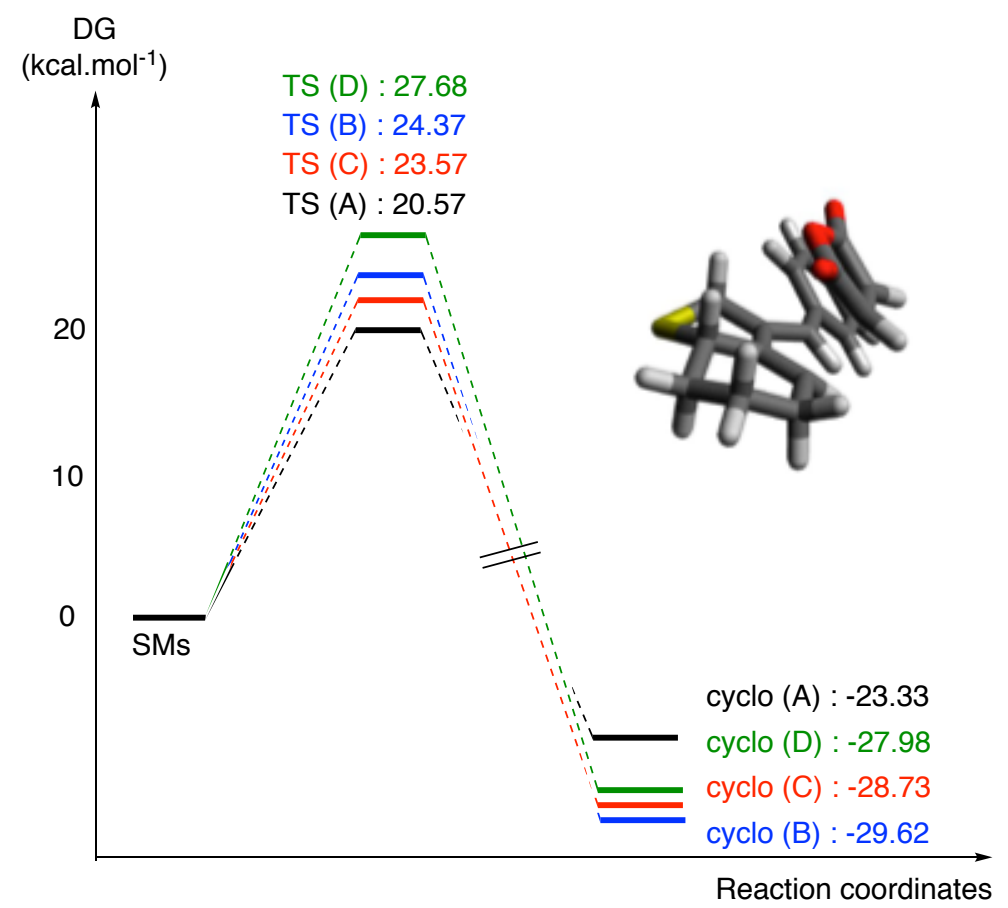

Figure 6. Schematic representation of the energy profile for the cycloaddition between $\mathbf{3 b}$ and $\mathbf{D 1}$ 


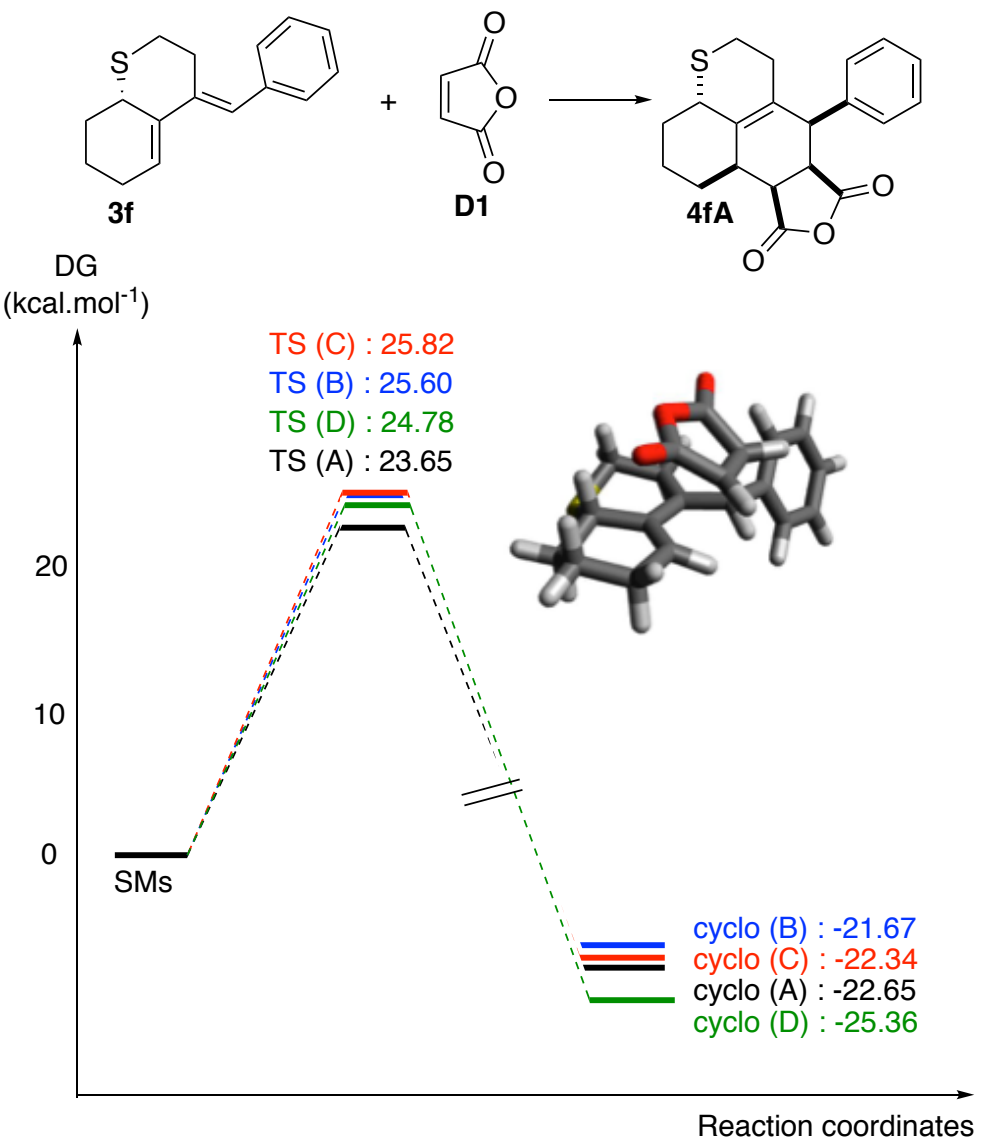

Figure 7. Schematic representation of the energy profile for the cycloaddition between $\mathbf{3 f}$ and $\mathbf{D 1}$

Computations involving the 6-membered ring diene $\mathbf{3 f}$ and diene D1 led to similar results. In this case also the top-endo approach (A) is the also most favored one, in line with the experimental results, albeit a much lower energy difference between the two most favorable TS is observed (Figure 7). Interestingly, the phenyl moiety of the diene is not conjugated with the dienic part (with a $\mathrm{C}^{\text {diene }}=\mathrm{CH}-\mathrm{C}=\mathrm{C}(\mathrm{Ph}) \mathrm{H}$ dihedral angle of $54.5^{\circ}$ ) in the optimized diene and is quasi perpendicular to the dienic part in the top/endo most favored TS (the $\mathrm{C}^{\text {diene }}=\mathrm{C}^{\text {diene }} \mathrm{H}-\mathrm{C}^{\mathrm{Ph}}=\mathrm{C}^{\mathrm{Ph}} \mathrm{H}$ dihedral angle being $78.48^{\circ}$ ), in sharp contrast with the 5 -membered ring system. The process remains a concerted, asynchronous one with the lengths of the forming bonds being $2.47 \AA$ and $2.08 \AA \mathrm{CH}^{\text {cyclo }}-\mathrm{C}^{\text {dienophile }}$ and $\mathrm{CH}^{\mathrm{Ph}}-\mathrm{C}^{\text {dienophile, }}$, respectively for the most favored top-endo TS. Noteworthy, the asynchronicity is more important, with the 6membered ring system, and the smallest forming bond is not the same, highlighting the strong influence of the thiacycle on the cycloaddition reaction. 


\section{Conclusions}

In summary, we developed a stereocontrolled synthesis of new sulfur-containing exo-bicyclic 1,3-dienes, based on palladium-catalyzed reductive cyclization of sulfur-linked 2bromoenynes. The method is efficient for both accessing 5- and 6-membered thiacyclic dienes. They have been reacted with several electron-deficient dienophiles leading to various original thiacycle-fused polycyclic systems, with high or total diastereoselectivity. Mechanistic details of the cycloadditions have been examined by computational means and the conclusions were in agreement with the experimental results.

\section{Experimental Part}

General information. Reagents were obtained from commercial sources and used without any further purification. Thin layer chromatography was performed on silica gel 60 F254 plates.

NMR spectra were recorded at 400 or $500 \mathrm{MHz}$ for ${ }^{1} \mathrm{H}$ and at 100 or $125 \mathrm{MHz}$ for ${ }^{13} \mathrm{C}$. Chemical shifts are reported in parts per million (ppm) relative to residual solvent and coupling constants $(\mathrm{J})$ are reported in hertz $(\mathrm{Hz}) . \mathrm{CDCl}_{3}$ was filtered previously on basic alumina. Assignments of ${ }^{1} \mathrm{H}$ and ${ }^{13} \mathrm{C}$ signal were made by DEPT, COSY, HSQC, HMBC, ADEQUATE, NOESY-2D, and selective NOESY-1D experiments. HRMS were performed with a Q-TOF analyzer Agilent 1200, using either electrospray ionization (ESI) at $\mathrm{T}_{\text {source }}=340{ }^{\circ} \mathrm{C}, \mathrm{V}_{\text {cap }}=4000 \mathrm{~V}$, or atmospheric pressure chemical ionization (APCI) at $\mathrm{T}_{\text {gas }}=300{ }^{\circ} \mathrm{C}, \mathrm{T}_{\text {vap }}=380^{\circ} \mathrm{C}, \mathrm{V}_{\text {corona }}=4 \mu \mathrm{A}$, or with an Agilent 7890 analyzer by using GC-MS (FI or EI). Melting points were determined in open capillary tubes and are uncorrected. (2-bromocyclohex-2-en-1-yl) ethanethioate (1). To a solution of 1,6-dibromocyclohex-1-ene (240 mg, $1 \mathrm{mmol}, 1$ equiv) in acetone $(200 \mathrm{~mL})$, potassium thioacetate $(126 \mathrm{mg}, 1.1 \mathrm{mmol}, 1.1$ equiv) was added. The reaction mixture was stirred at room temperature for one night. After filtration of the potassium bromide salts, the filtrate was concentrated under reduced pressure and the residue was purified by flash column chromatography on silica gel (heptane) to afford thioacetate $\mathbf{1}(235 \mathrm{mg}$, $100 \%$ yield).

${ }^{1} \mathbf{H}$ NMR $\left(\mathrm{CDCl}_{3}, 400 \mathrm{MHz}\right) \delta 1.59(\mathrm{~m}, 1 \mathrm{H}), 1.75(\mathrm{~m}, 1 \mathrm{H}), 1.96(\mathrm{~m}, 1 \mathrm{H}), 2.09-2.18(\mathrm{~m}, 3 \mathrm{H}), 2.35(\mathrm{~s}$, $\left.3 \mathrm{H}, \mathrm{CH}_{3}\right), 4.37$ (bs, 1H, SCH), $6.19(\mathrm{t}, J=4.0 \mathrm{~Hz}, 1 \mathrm{H}, \mathrm{C}=\mathrm{CH}) \cdot{ }^{13} \mathbf{C} \mathbf{N M R}\left(\mathrm{CDCl}_{3}, 100.6 \mathrm{MHz}\right) \delta 17.9$ $\left(\mathrm{CH}_{3}\right), 27.4\left(\mathrm{CH}_{2}\right), 30.5\left(\mathrm{CH}_{2}\right), 31.7\left(\mathrm{CH}_{2}\right), 48.2(\mathrm{SCH}), 120.3(\mathrm{CBr}), 133.8(\mathrm{C}=\underline{\mathrm{CH}}), 194.6(\mathrm{C}=\mathrm{O})$.

\section{Synthesis and characterization of sulfides (2a-f)}

(2-bromocyclohex-2-en-1-yl)(pent-2-yn-1-yl)sulfane (2a) To a solution of KOH (657 mg, 11.7 mmol, 1.5 equiv) in ethanol $(130 \mathrm{~mL})$, thioacetate 1 (1.83 g, $7.80 \mathrm{mmol}, 1$ equiv) and 3-(ethyl)propargyl bromide (1.26 g, $8.58 \mathrm{mmol}, 1.1$ equiv) were added successively. The reaction mixture was stirred at room temperature for $15 \mathrm{~min}$. After evaporation of the solvent, hydrolysis by water and extraction with ether, the organic layers were separated, dried with $\mathrm{MgSO}_{4}$ and the solution was concentrated 
under reduced pressure. The residue was purified by flash column chromatography on silica gel (eluent: heptane) to afford 2a (1.6 g, 80\% yield).

${ }^{1} \mathbf{H}$ NMR $\left(\mathrm{CDCl}_{3}, 400 \mathrm{MHz}\right) \delta 1.16\left(\mathrm{t}, J=7.5 \mathrm{~Hz}, 3 \mathrm{H}, \mathrm{CH}_{3}\right), 1.71(\mathrm{~m}, 1 \mathrm{H}), 1.86(\mathrm{~m}, 1 \mathrm{H}), 2.04-2.17$ (m, 4H, 2xCH$), 2.24\left(\mathrm{tq}, J=2.3,7.6 \mathrm{~Hz}, 2 \mathrm{H}, \mathrm{CH}_{3} \mathrm{CH}_{2}\right), 3.39$ (t, $\left.J=2.3 \mathrm{~Hz}, 2 \mathrm{H}, \mathrm{SCH}_{2}\right), 3.70(\mathrm{~s}, 1 \mathrm{H}$, $\mathrm{SCH}), 6.16(\mathrm{t}, J=3.8 \mathrm{~Hz}, 1 \mathrm{H}, \mathrm{BrC}=\mathrm{C} \underline{\mathrm{H}}) .{ }^{13} \mathrm{C} \mathbf{N M R}\left(\mathrm{CDCl}_{3}, 100.6 \mathrm{MHz}\right) \delta 12.5\left(\mathrm{CH}_{3}\right), 14.0$ $\left(\mathrm{CH}_{3} \underline{\mathrm{CH}_{2}}\right), 13.3\left(\mathrm{SCH}_{2}\right), 20.9\left(\mathrm{CH}_{2}\right), 20.5\left(\mathrm{CH}_{2}\right), 30.9\left(\mathrm{CH}_{2}\right), 49.4(\mathrm{SCH}), 74.9(\mathrm{Cq}), 85.4(\mathrm{Cq}), 122.4$ $(\mathrm{CBr}), 132.5(\mathrm{BrC}=\underline{\mathrm{CH}})$. HRMS (FI+eiFi) $\mathbf{m} / \mathbf{z}$ : $\left[\mathrm{M}^{+}\right]$calculated for $\mathrm{C}_{11} \mathrm{H}_{15} \mathrm{BrS} 258.0078$, found 258.0083 .

(2-bromocyclohex-2-en-1-yl)(3-phenylprop-2-yn-1-yl)sulfane (2b) To a solution of $\mathrm{KOH}$ (716 mg, $12.8 \mathrm{mmol}, 1.5$ equiv) in ethanol (78 mL), thioacetate 1 ( $2 \mathrm{~g}, 8.5 \mathrm{mmol}, 1$ equiv) and (3-chloroprop-1yn-1-yl)benzene (1.28 g, $8.5 \mathrm{mmol}, 1$ equiv) were added successively. The reaction mixture was stirred at room temperature for one hour. After evaporation of the solvent, hydrolysis by water and extraction with ether, the organic phases were separated, dried with $\mathrm{MgSO}_{4}$ and the solution was concentrated under reduced pressure. The residue was purified by flash column chromatography on silica gel (heptane) to afford $\mathbf{2 b}(1.43 \mathrm{~g}, 55 \%$ yield).

${ }^{1} \mathbf{H}$ NMR $\left(\mathrm{CDCl}_{3}, 400 \mathrm{MHz}\right) \delta 1.70(\mathrm{~m}, 1 \mathrm{H}), 1.85(\mathrm{~m}, 1 \mathrm{H}), 1.94-2.17\left(\mathrm{~m}, 4 \mathrm{H}, \mathrm{CH}_{2}\right), 3.62(\mathrm{~s}, 2 \mathrm{H}$, $\left.\mathrm{SCH}_{2}\right), 3.77$ (bs, 1H, SCH), $6.11(\mathrm{t}, J=4.0 \mathrm{~Hz}, 1 \mathrm{H}, \mathrm{BrC}=\mathrm{C} \underline{\mathrm{H}}), 7.21-7.26(\mathrm{~m}, 3 \mathrm{H}), 7.37-7.39(\mathrm{~m}, 2 \mathrm{H})$. ${ }^{13} \mathrm{C}$ NMR $\left(\mathrm{CDCl}_{3}, 100.6 \mathrm{MHz}\right) \delta 17.5\left(\mathrm{SCH}_{2}\right), 21.5\left(\mathrm{CH}_{2}\right), 27.74\left(\mathrm{CH}_{2}\right), 31.19\left(\mathrm{CH}_{2}\right), 49.90(\mathrm{SCH})$, $83.70(\mathrm{Cq}), 85.54(\mathrm{Cq}), 122.37(\mathrm{Cq}), 123.1(\mathrm{Cq}), 128.4(\mathrm{CH}), 128.5(2 \times \mathrm{CH}), 131.9(2 \mathrm{xCH}), 133.0$ (CBr). HRMS (ESI/Q-TOF) $\mathbf{m} / \mathbf{z}:\left[\mathrm{M}+\mathrm{H}^{+}\right]$calculated for $\mathrm{C}_{15} \mathrm{H}_{16} \mathrm{BrS} 307.0151$, found 307.0143 .

4-((2-bromocyclohex-2-en-1-yl)thio)but-2-yn-1-ol (2c) To a solution of KOH (286 mg, $5.10 \mathrm{mmol}, 1.5$ equiv) in ethanol ( $40 \mathrm{~mL})$, thioacetate 1 ( $800 \mathrm{mg}, 3.40 \mathrm{mmol}, 1$ equiv) and 4-chlorobut-2-yn-1-ol (391 $\mathrm{mg}, 3.74 \mathrm{mmol}, 1.1$ equiv) were added successively. The reaction mixture was stirred at room temperature for 5 hours. After evaporation of the solvent, hydrolysis by $\mathrm{NH}_{4} \mathrm{Cl}$ and extraction with ether, the organic layers were separated, dried on $\mathrm{Na}_{2} \mathrm{SO}_{4}$ and the solution was concentrated under reduced pressure. The residue was purified by flash column chromatography on silica gel (heptane/ AcOEt 80/20) to afford $\mathbf{2 c}(789 \mathrm{mg}, 89 \%)$.

${ }^{1} \mathbf{H}$ NMR $\left(\mathrm{CDCl}_{3}, 400 \mathrm{MHz}\right) \delta 1.71(\mathrm{~m}, 1 \mathrm{H}), 1.83(\mathrm{~m}, 1 \mathrm{H}), 2.04-2.17\left(\mathrm{~m}, 4 \mathrm{H}, 2 \mathrm{xCH}_{2}\right), 3.41(\mathrm{~s}, 2 \mathrm{H}$, $\left.\mathrm{SCH}_{2}\right), 3.66(\mathrm{~s}, 1 \mathrm{H}, \mathrm{SCH}), 4.30\left(\mathrm{~d}, J=\left(5.1 \mathrm{~Hz}, 2 \mathrm{H}, \mathrm{OCH}_{2}\right), 6.15(\mathrm{dd}, J=4.6,3.5 \mathrm{~Hz}, 1 \mathrm{H}, \mathrm{BrC}=\mathrm{C} \underline{\mathrm{H}})\right.$.

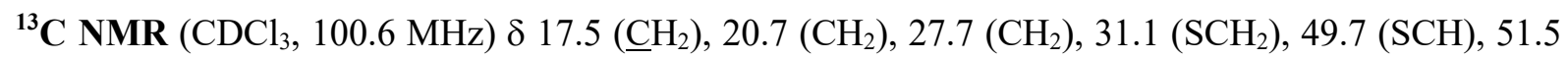
$\left(\mathrm{OCH}_{2}\right), 81.7(\mathrm{Cq}), 82.1(\mathrm{Cq}), 122.2(\mathrm{CBr}), 133.0(\mathrm{C}=\underline{\mathrm{CH}})$. HRMS (ESI/Q-TOF) m/z: $\left[\mathrm{M}+\mathrm{H}^{+}\right]$ calculated for $\mathrm{C}_{10} \mathrm{H}_{14} \mathrm{BrOS} 260.9943$, found 260.9938 .

(2-bromocyclohex-2-en-1-yl)(pent-3-yn-1-yl)sulfane (2d) To a solution of KOH (260 mg, $4.6 \mathrm{mmol}$, 1.5 equiv) in ethanol $(40 \mathrm{~mL}), \mathrm{S}-(2$-bromocyclohex-2-en-1-yl) thioacetate 1 (730 mg, $3 \mathrm{mmol}, 1$ equiv), 18-crown-6 (170 mg ;0,46 mmol, 0,15 equiv), and then 5-bromopent-2-yne (670 mg, 3.7 
mmol, 1.2 equiv) were added successively. The reaction mixture was stirred at room temperature for 3 hours. After evaporation of the solvent, ether was added, then the insoluble solid removed by filtration. The solution was concentrated under reduced pressure. The residue was purified by flash column chromatography on silica gel (heptane/AcOEt 99:1) to afford $\mathbf{2 d}$ (653 mg 81\% yield).

${ }^{1} \mathrm{H}$ NMR $\left(\mathrm{CDCl}_{3}, 400 \mathrm{MHz}\right) \delta 1.67(\mathrm{~m}, 1 \mathrm{H}), 1.77\left(\mathrm{~s}, 3 \mathrm{H}, \mathrm{CH}_{3}\right), 1.79(\mathrm{~m}, 1 \mathrm{H}), 2.03-2.08(\mathrm{~m}, 4 \mathrm{H}$, $\left.2 \mathrm{xCH}_{2}\right), 2.43-2.45\left(\mathrm{~m}, 2 \mathrm{H}, \mathrm{CH}_{2}\right), 2.75\left(\mathrm{t}, \mathrm{J}=7.4 \mathrm{~Hz}, 2 \mathrm{H}, \mathrm{SCH}_{2}\right), 3.46(\mathrm{~s}, 1 \mathrm{H}, \mathrm{SCH}), 6.08(\mathrm{t}, \mathrm{J}=3.8$ $\mathrm{Hz}, 1 \mathrm{H}, \mathrm{CBr}=\mathrm{CH}) .{ }^{13} \mathrm{C} \mathrm{NMR}\left(\mathrm{CDCl}_{3}, 100.6 \mathrm{MHz}\right) \delta 3.7\left(\mathrm{CH}_{3}\right), 17.5\left(\mathrm{CH}_{2}\right), 20.7\left(\mathrm{CH}_{2}\right), 27.6\left(\mathrm{CH}_{2}\right)$, $31.7\left(\mathrm{CH}_{2}\right), 32.3\left(\mathrm{CH}_{2}\right), 50.1(\mathrm{SCH}), 70.0(\equiv \mathrm{C}), 76.9(\equiv \mathrm{C}), 122.9(\mathrm{CBr}), 132.3(=\mathrm{CH}) . \mathbf{H R M S}(\mathbf{E S I} / \mathbf{Q}-$ TOF) $\mathbf{~ m / z : ~}\left[\mathrm{M}+\mathrm{H}^{+}\right]$calculated for $\mathrm{C}_{11} \mathrm{H}_{16} \mathrm{BrS} 259.0151$, found 259.0141 .

(2-bromocyclohex-2-en-1-yl)(but-3-yn-1-yl)sulfane (2e). To a solution of KOH (358 mg, $6.3 \mathrm{mmol}$, 1.5 equiv) in ethanol ( $40 \mathrm{~mL}), \mathrm{S}-(2$-bromocyclohex-2-en-1-yl) thioacetate 1 ( $1 \mathrm{~g}, 4.25 \mathrm{mmol}, 1$ equiv), 18-crown-6 (169 mg, $0.63 \mathrm{mmol}, 0.15$ equiv), and 4-bromobut-1-yne (566 mg, $4.25 \mathrm{mmol}, 1$ equiv) were added successively. The reaction mixture was stirred at room temperature for 3 hours. After evaporation of the solvent, ether was added, then the insoluble solid was removed by filtration. The solution was concentrated under reduced pressure. The residue was purified by flash column chromatography on silica gel (heptane/AcOEt) to afford 2 e (791 $\mathrm{mg} 76 \%$ yield).

${ }^{1} \mathrm{H}$ NMR $\left(\mathrm{CDCl}_{3}, 400 \mathrm{MHz}\right) \delta 1.67(\mathrm{~m}, 1 \mathrm{H}), 1.83(\mathrm{~m}, 1 \mathrm{H}), 2.03-2.12\left(\mathrm{~m}, 5 \mathrm{H}, 2 \mathrm{xCH}_{2} \& \mathrm{C} \equiv \mathrm{CH}\right), 2.49$ $2.56\left(\mathrm{~m}, 2 \mathrm{H}, \mathrm{CH}_{2}\right), 2.82\left(\mathrm{t}, \mathrm{J}=7.4 \mathrm{~Hz}, 2 \mathrm{H}, \mathrm{SCH}_{2}\right), 3.47(\mathrm{~s}, 1 \mathrm{H}, \mathrm{SCH}), 6.11(\mathrm{t}, \mathrm{J}=3.8 \mathrm{~Hz}, 1 \mathrm{H}$, $\mathrm{CBr}=\mathrm{CH}) .{ }^{13} \mathrm{C} \mathrm{NMR}\left(\mathrm{CDCl}_{3}, 100.6 \mathrm{MHz}\right) \delta 17.4\left(\mathrm{CH}_{2}\right), 20.4\left(\mathrm{CH}_{2}\right), 27.6\left(\mathrm{CH}_{2}\right), 31.7\left(2 \mathrm{xCH}_{2}\right), 50.2$ $(\mathrm{SCH}), 69.6(\mathrm{HC} \equiv), 82.7(\equiv \mathrm{C}), 122.7(\mathrm{CBr}), 132.5(=\mathrm{CH})$. HRMS (APCI/Q-TOF) m/z: $\left[\mathrm{M}+\mathrm{H}^{+}\right]$ calculated for $\mathrm{C}_{10} \mathrm{H}_{14} \mathrm{BrS} 245.0000$, found 244.9987

(2-bromocyclohex-2-en-1-yl)(4-phenylbut-3-yn-1-yl)sulfane (2f). Under argon atmosphere, were added successively copper iodide ( 0.1 equiv, $0.04 \mathrm{mmol}, 7.7 \mathrm{mg}$ ), $\mathrm{Pd}(\mathrm{OAc})_{2}$ (4.6 mg, $0.02 \mathrm{mmol}, 0.05$ equiv), $\mathrm{PPh}_{3}$ (10.7 mg, $0.04 \mathrm{mmol}, 0.1$ equiv), phenyl iodide (120 mg, $0.4 \mathrm{mmol}, 1$ equiv), then the mixture was dissolved in distilled diisopropylamine $(1 \mathrm{~mL})$. Then, homopropargyl sulfide $2 \mathbf{e}(107 \mathrm{mg}$, $0.4 \mathrm{mmol}, 1$ equiv) was added and the mixture was stirred at room temperature for $12 \mathrm{~h}$. The reaction mixture was then filtered through Celite to eliminate the metal traces and then concentrated under reduced pressure. The crude product was purified by flash column chromatography (eluent: heptane/AcOEt 95/5), to afford pure $\mathbf{2 f}$ (108 $\mathrm{mg} 84 \%$ yield).

${ }^{1} \mathrm{H}$ NMR $\left(\mathrm{CDCl}_{3}, 400 \mathrm{MHz}\right) \delta 1.67(\mathrm{~m}, 1 \mathrm{H}), 1.86(\mathrm{~m}, 1 \mathrm{H}), 2.07-2.11\left(\mathrm{~m}, 4 \mathrm{H}, 3 \mathrm{xCH}_{2}\right), 2.75-2.78(\mathrm{~m}$, $\left.2 \mathrm{H}, \mathrm{CH}_{2}\right), 2.87-2.91\left(\mathrm{~m}, 2 \mathrm{H}, \mathrm{SCH}_{2}\right), 3.54(\mathrm{~s}, 1 \mathrm{H}, \mathrm{SCH}), 6.15(\mathrm{t}, \mathrm{J}=3.8 \mathrm{~Hz}, 1 \mathrm{H}, \mathrm{CBr}=\mathrm{CH}), 7.26-7.28$ (m, 3H), 7.39-7.41 (m, 2H). ${ }^{13} \mathrm{C}$ NMR $\left(\mathrm{CDCl}_{3}, 100.6 \mathrm{MHz}\right) \delta 17.5\left(\mathrm{CH}_{2}\right), 21.5\left(\mathrm{CH}_{2}\right), 27.6\left(\mathrm{CH}_{2}\right)$, $31.7\left(\mathrm{CH}_{2}\right), 32.0\left(\mathrm{CH}_{2}\right), 50.2(\mathrm{SCH}), 81.8(\equiv \mathrm{C}), 88.3(\mathrm{PhC} \equiv), 122.9(\mathrm{Cq}), 123.7(\mathrm{Cq}), 128.0(\mathrm{CH})$, $128.4(2 \times C H), 131.8(2 \times C H), 132.5(\mathrm{CH})$. HRMS (ESI/Q-TOF) $\mathbf{m} / \mathbf{z}:\left[\mathrm{M}+\mathrm{H}^{+}\right]$calculated for $\mathrm{C}_{16} \mathrm{H}_{18} \mathrm{BrS} 321.0313$, found 321.0309 . 
Synthesis and characterization of dienes (3a-f). General procedure: To a solution of sulfide 2 (1 equiv) in DMF, were successively added ammonium formate (1.5 equiv), $\mathrm{Pd}(\mathrm{OAc})_{2}(0.1$ equiv) and $\mathrm{PPh}_{3}\left(0.2\right.$ equiv). After $2 \mathrm{~h}$ at $100{ }^{\circ} \mathrm{C}$, the reaction mixture was cooled to room temperature and water was added to remove the DMF. After extraction with ethyl acetate, the combined organic phases were washed with brine, dried with $\mathrm{MgSO}_{4}$, filtered and concentrated under reduced pressure. The crude material was purified by flash chromatography (cyclohexane/toluene 95/5) to give diene 3 .

(Z)-3-propylidene-2,3,5,6,7,7a-hexahydrobenzo[b]thiophene (3a). Following the general procedure, sulfide 2a (456 mg, $1.76 \mathrm{mmol}, 1$ equiv) was used with ammonium formate (166 mg, $2.64 \mathrm{mmol}, 1.5$ equiv), $\mathrm{Pd}(\mathrm{OAc})_{2}\left(39 \mathrm{mg}, 0.18 \mathrm{mmol}, 0.1\right.$ equiv) and $\mathrm{PPh}_{3}(92 \mathrm{mg}, 0.35 \mathrm{mmol}, 0.2$ equiv) to afford diene 3a as colorless oil (217 mg, 68\%).

${ }^{1} \mathbf{H}$ NMR $\left(\mathrm{CDCl}_{3}, 400 \mathrm{MHz}\right) \delta 1.01\left(\mathrm{t}, J=7.6 \mathrm{~Hz}, 3 \mathrm{H}, \mathrm{CH}_{3}\right), 1.38(\mathrm{~m}, 1 \mathrm{H}), 1.50(\mathrm{~m}, 1 \mathrm{H}), 1.90(\mathrm{~m}$, $1 \mathrm{H}), 2.05-2.11\left(\mathrm{~m}, 2 \mathrm{H}, \mathrm{C}_{2} \mathrm{CH}_{3}\right), 2.13-2.22(\mathrm{~m}, 3 \mathrm{H}), 3.49\left(\mathrm{~s}, 2 \mathrm{H}, \mathrm{SCH}_{2}\right), 3.74(\mathrm{~m}, 1 \mathrm{H}, \mathrm{SCH}), 5.75(\mathrm{t}, J$ $=7.5 \mathrm{~Hz}, 1 \mathrm{H}, \mathrm{C}=\mathrm{C} \underline{\mathrm{H}}), 5.89(\mathrm{bs}, 1 \mathrm{H}, \mathrm{C}=\mathrm{C} \underline{\mathrm{H}}) .{ }^{13} \mathbf{C} \mathbf{~ N M R}\left(\mathrm{CDCl}_{3}, 100.6 \mathrm{MHz}\right) \delta 14.0\left(\mathrm{CH}_{3}\right), 22.4$ $\left(\mathrm{CH}_{2}\right), 22.9\left(\mathrm{CH}_{2}\right), 25.0\left(\mathrm{CH}_{2}\right), 29.5\left(\mathrm{CH}_{2}\right), 31.7\left(\mathrm{SCH}_{2}\right), 46.4(\mathrm{SCH}), 117.6(\mathrm{C}=\underline{\mathrm{CH}}), 122.5(\mathrm{Cq})$, $137.7(\mathrm{C}=\mathrm{C} \underline{\mathrm{H}}), 140.8(\mathrm{Cq})$. HRMS (APCI/Q-TOF) m/z: $\left[\mathrm{M}+\mathrm{H}^{+}\right]$calculated for $\mathrm{C}_{11} \mathrm{H}_{17} \mathrm{~S} 181.1045$, found 181.1041 .

(Z)-3-benzylidene-2,3,5,6,7,7a-hexahydrobenzo[b]thiophene (3b). Following the general procedure, sulfide $2 \mathbf{b}$ (498 mg, $1.63 \mathrm{mmol}, 1$ equiv) was used with ammonium formate (154 mg, $2.44 \mathrm{mmol}, 1.5$ equiv), $\mathrm{Pd}(\mathrm{OAc})_{2}\left(36 \mathrm{mg}, 0.16 \mathrm{mmol}, 0.1\right.$ equiv) and $\mathrm{PPh}_{3}(85 \mathrm{mg}, 0.32 \mathrm{mmol}, 0.2$ equiv) to afford diene $\mathbf{3 b}$ as colorless oil (223 $\mathrm{mg}, 60 \%)$.

${ }^{1} \mathbf{H}$ NMR $(\mathrm{CDCl} 3,400 \mathrm{MHz}) \delta 1.39-1.49\left(\mathrm{~m}, 1 \mathrm{H}, \mathrm{CH}_{2}\right), 1.58-1.63\left(\mathrm{~m}, 1 \mathrm{H}, \mathrm{CH}_{2}\right), 1.93-1.98(\mathrm{~m}, 1 \mathrm{H}$, $\mathrm{CH}_{2}$ ), 2.24-2.27 (m, 3H, $\mathrm{CH}_{2}$ ), 3.77-3.83 (m, 1H, SCH), 3.84 (s, 2H, $\left.\mathrm{SCH}_{2}\right), 6.13(\mathrm{~s}, 1 \mathrm{H}, \mathrm{C}=\mathrm{C} \underline{\mathrm{H}}), 6.77$ $(\mathrm{s}, 1 \mathrm{H}, \mathrm{C}=\mathrm{C} \underline{\mathrm{H}}), 7.21-7.24(\mathrm{~m}, 1 \mathrm{H}), 7.31-7.35(\mathrm{~m}, 4 \mathrm{H}) .{ }^{13} \mathbf{C} \mathbf{N M R}\left(\mathrm{CDCl}_{3}, 100.6 \mathrm{MHz}\right) \delta 17.5\left(\mathrm{CH}_{2}\right)$, $21.5\left(\mathrm{CH}_{2}\right), 27.7\left(\mathrm{CH}_{2}\right), 31.2\left(\mathrm{SCH}_{2}\right), 49.9(\mathrm{SCH}), 122.4(\mathrm{C}=\underline{\mathrm{CH}}), 123.2(\mathrm{C}=\underline{\mathrm{CH}}), 128.4(\mathrm{CH}), 128.5$ $(2 \times C H), 128.6(\underline{\mathrm{C}}=\mathrm{CH}), 129.0(\mathrm{Cq}), 131.9(2 \mathrm{xCH}), 133.0(\underline{\mathrm{C}}=\mathrm{CH})$. HRMS (ESI/Q-TOF) m/z: $\left[\mathrm{M}+\mathrm{H}^{+}\right]$calculated for $\mathrm{C}_{15} \mathrm{H}_{17} \mathrm{~S} 229.1045$, found 229.1044 .

(Z)-2-(5,6,7,7a-tetrahydrobenzo[b]thiophen-3(2H)-ylidene)ethan-1-ol (3c). Following the general procedure, sulfide $2 \mathbf{c}$ (100 $\mathrm{mg}, 0.38 \mathrm{mmol}, 1$ equiv) was used with ammonium formate (36 $\mathrm{mg}, 0,57$ mmol, 1.5 equiv), $\mathrm{Pd}(\mathrm{OAc})_{2}\left(9 \mathrm{mg}, 0.04 \mathrm{mmol}, 0.1\right.$ equiv) and $\mathrm{PPh}_{3}(20 \mathrm{mg}, 0.07 \mathrm{mmol}, 0.2$ equiv) to afford diene $3 \mathbf{c}$ as colorless oil ( $32 \mathrm{mg}, 46 \%$ ).

${ }^{1} \mathbf{H}$ NMR $\left(\mathrm{CDCl}_{3}, 400 \mathrm{MHz}\right) \delta 1.32-1.41(\mathrm{~m}, 2 \mathrm{H}), 1.55(\mathrm{~m}, 1 \mathrm{H}), 1.90(\mathrm{~m}, 1 \mathrm{H}), 2.13-2.22(\mathrm{~m}, 3 \mathrm{H}), 3.54$ (s, 2H, $\left.\mathrm{SCH}_{2}\right), 3.72(\mathrm{~m}, 1 \mathrm{H}, \mathrm{SCH}), 4.24$ (d, $\left.J=6.8 \mathrm{~Hz}, 2 \mathrm{H}, \mathrm{OCH}_{2}\right), 5.93$, (t, $\left.J=7.0 \mathrm{~Hz}, 1 \mathrm{H}, \mathrm{C}=\mathrm{C} \underline{\mathrm{H}}\right)$, 6.01 (bs, 1H, C=C杰). ${ }^{13} \mathrm{C}$ NMR $\left(\mathrm{CDCl}_{3}, 100.6 \mathrm{MHz}\right) \delta 22.1\left(\mathrm{CH}_{2}\right), 24.9\left(\mathrm{CH}_{2}\right), 29.2\left(\mathrm{CH}_{2}\right), 31.4$ $\left(\mathrm{CH}_{2}\right), 45.9(\mathrm{SCH}), 60.5\left(\mathrm{OCH}_{2}\right), 118.4(\mathrm{C}=\underline{\mathrm{CH}}), 119.7(\mathrm{C}=\mathrm{C} \underline{\mathrm{H}}), 140.3(\mathrm{Cq}), 140.6(\mathrm{Cq})$. HRMS (ESI/Q-TOF) $\mathbf{m} / \mathbf{z}$ : $\left[\mathrm{M}+\mathrm{H}^{+}\right]$calculated for $\mathrm{C}_{10} \mathrm{H}_{15} \mathrm{OS} 183.0838$, found 183.0829 . 
(E)-4-ethylidene-3,4,6,7,8,8a-hexahydro-2H-thiochromene (3d). Following the general procedure, sulfide $2 \mathrm{~d}$ (286 mg, $1.1 \mathrm{mmol}, 1$ equiv) was used with ammonium formate (104 mg, $1.65 \mathrm{mmol}, 1.5$ equiv), $\mathrm{Pd}(\mathrm{OAc})_{2}\left(24 \mathrm{mg}, 0.11 \mathrm{mmol}, 0.1\right.$ equiv) and $\mathrm{PPh}_{3}(58 \mathrm{mg}, 0.22 \mathrm{mmol}, 0.2$ equiv), in $1 \mathrm{~mL}$ DMF, to afford diene $\mathbf{3 d}$ as colorless oil (110 mg, 55\%).

${ }^{1} \mathbf{H}$ NMR $\left(\mathrm{CDCl}_{3}, 400 \mathrm{MHz}\right) \delta 1.53-1.59(\mathrm{~m}, 1 \mathrm{H}), 1.62\left(\mathrm{~d}, J=6.7 \mathrm{~Hz}, 3 \mathrm{H}, \mathrm{CH}_{3}\right), 1.73-1.79(\mathrm{~m}, 1 \mathrm{H})$, 1.99-2.05 (m, 2H), $2.11(\mathrm{~m}, 1 \mathrm{H}), 2.28(\mathrm{~m}, 1 \mathrm{H}), 2.67-2.80(\mathrm{~m}, 3 \mathrm{H}), 2.90(\mathrm{~m}, 1 \mathrm{H}), 3.49(\mathrm{~m}, 1 \mathrm{H}, \mathrm{SCH})$, $5.44(\mathrm{q}, J=7.2 \mathrm{~Hz}, 1 \mathrm{H}, \mathrm{C}=\mathrm{C} \underline{\mathrm{H}}), 5.65$ (bs, $1 \mathrm{H}, \mathrm{C}=\mathrm{C} \underline{\mathrm{H}}) .{ }^{13} \mathbf{C} \mathbf{N M R}\left(\mathrm{CDCl}_{3}, 100.6 \mathrm{MHz}\right) \delta 13.3\left(\mathrm{CH}_{3}\right)$, $21.1\left(\mathrm{CH}_{2}\right), 25.9\left(\mathrm{CH}_{2}\right), 29.2\left(\mathrm{CH}_{2}\right), 30.0\left(\mathrm{CH}_{2}\right), 30.7\left(\mathrm{CH}_{2}\right), 40.5(\mathrm{SCH}), 119.8(\mathrm{CH}), 122.1(\mathrm{CH})$, $140.2(\mathrm{Cq}), 141.0(\mathrm{Cq})$. HRMS (APCI/Q-TOF) m/z: $\left[\mathrm{M}+\mathrm{H}^{+}\right]$calculated for $\mathrm{C}_{11} \mathrm{H}_{17} \mathrm{~S} 181.1045$, found 181.1041.

4-methylene-3,4,6,7,8,8a-hexahydro-2H-thiochromene (3e). Following the general procedure, sulfide 2e (100 mg, $0.41 \mathrm{mmol}, 1$ equiv) was used with ammonium formate ( $39 \mathrm{mg}, 0.61 \mathrm{mmol}, 1.5$ equiv), $\mathrm{Pd}(\mathrm{OAc})_{2}\left(9 \mathrm{mg}, 0.041 \mathrm{mmol}, 0.1\right.$ equiv) and $\mathrm{PPh}_{3}(21 \mathrm{mg}, 0.082 \mathrm{mmol}, 0.2$ equiv), in $2 \mathrm{~mL} \mathrm{DMF}$, to afford diene 3e. The crude product obtained (characterized by ${ }^{1} \mathrm{H}-\mathrm{NMR}$ ) after extraction was directly used in cycloaddition.

${ }^{1} \mathbf{H}$ NMR $\left(\mathrm{CDCl}_{3}, 400 \mathrm{MHz}\right) \delta 1.5(\mathrm{t}, \mathrm{J}=7.5 \mathrm{~Hz}, 1 \mathrm{H}), 1.62-1.64(\mathrm{~m}, 2 \mathrm{H}), 2.04-2.07(\mathrm{~m}, 2 \mathrm{H}), 2.48-$ $2.55(\mathrm{~m}, 2 \mathrm{H}), 2.64-2.70(\mathrm{~m}, 2 \mathrm{H}), 2.79-2.86(\mathrm{~m}, 1 \mathrm{H}), 3.46-3.51(\mathrm{~m}, 1 \mathrm{H}), 4.66(\mathrm{~s}, 1 \mathrm{H},=\mathrm{CH}), 4.86(\mathrm{~s}$, $1 \mathrm{H},=\mathrm{CH}), 5.78(\mathrm{~s}, 1 \mathrm{H},=\mathrm{CH})$.

(E)-4-benzylidene-3,4,6,7,8,8a-hexahydro-2H-thiochromene (3f). Following the general procedure, to a solution of sulfide $2 \mathbf{f}$ ( $264 \mathrm{mg}, 0.8 \mathrm{mmol}, 1$ equiv) in DMF (5 mL), were successively added ammonium formate ( $78 \mathrm{mg}, 1.2 \mathrm{mmol}, 1.6$ equiv, $0.5 \mathrm{mmol}), \mathrm{Pd}(\mathrm{OAc})_{2}(18 \mathrm{mg}, 0.08 \mathrm{mmol}, 0.1$ equiv) and $\mathrm{PPh}_{3}$ (43 mg, $0.2 \mathrm{mmol}, 0.2$ equiv). After $2 \mathrm{~h}$ at $100{ }^{\circ} \mathrm{C}$, the reaction mixture was cooled to room temperature and water was added to remove the DMF. After extraction with ethyl acetate, the combined organic phases were washed with water, dried with $\mathrm{MgSO} 4$, filtered and concentrated under reduced pressure. The crude material was purified by chromatography (cyclohexane/toluene 95/5) to afford diene $\mathbf{3 f}$ as colorless oil (151 $\mathrm{mg}, 78 \%$ ).

${ }^{1} \mathbf{H}$ NMR $\left(\mathrm{CDCl}_{3}, 400 \mathrm{MHz}\right) \delta 1.53-1.59(\mathrm{~m}, 2 \mathrm{H}), 1.81(\mathrm{~m}, 1 \mathrm{H}), 2.08-2.20(\mathrm{~m}, 3 \mathrm{H}), 2.44-2.80(\mathrm{~m}$,

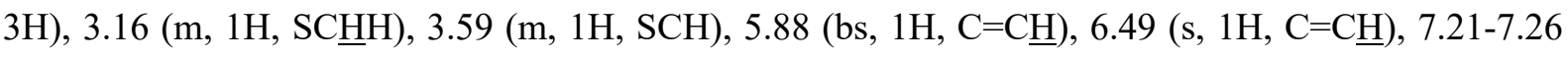
$(\mathrm{m}, 3 \mathrm{H}), 7.32-7.34(\mathrm{~m}, 2 \mathrm{H}) .{ }^{13} \mathrm{C}$ NMR $\left(\mathrm{CDCl}_{3}, 100.6 \mathrm{MHz}\right) \delta 22.0\left(\mathrm{CH}_{2}\right), 26.1\left(\mathrm{CH}_{2}\right), 29.3\left(\mathrm{CH}_{2}\right)$, $30.0\left(\mathrm{CH}_{2}\right), 32.2\left(\mathrm{CH}_{2}\right), 40.4(\mathrm{SCH}), 123.8(\mathrm{CH}), 125.7(\mathrm{CH}), 126.7(\mathrm{CH}), 128.3(2 \times \mathrm{CH}), 129.4$ $(2 \times C H), 137.8(\mathrm{Cq}), 140.8(\mathrm{Cq}), 142.1(\mathrm{Cq})$. HRMS (ESI/Q-TOF) m/z: [M+H $\left.{ }^{+}\right]$calculated for $\mathrm{C}_{16} \mathrm{H}_{19} \mathrm{~S} 243.1207$, found 243.1195.

Diels-Alder reactions. Synthesis and characterization of cycloadducts (4-10) Cycloadditions of diene (3a)

6-ethyl-1,2,3,3a,6,6a,9a,9b-octahydro-5H-thieno[4',3',2':4,5]naphtho[1,2-c]furan-7,9-dione (4aA) 
A mixture of diene 3a (50 mg, $0.28 \mathrm{mmol}, 1.1$ equiv) and maleic anhydride $\mathbf{D 1}$ (27 mg, $0.25 \mathrm{mmol}, 1$ equiv) was stirred $2 \mathrm{~h}$ at $40{ }^{\circ} \mathrm{C}$ in dichloromethane $(0.5 \mathrm{~mL})$. The product was then purified by flash chromatography (heptane/ethyl acetate 9/1) and obtained as an inseparable mixture of two diastereomers in $8 / 2$ ratio, as a white paste $(63 \mathrm{mg}, 91 \%)$.

Major stereoisomer 4aA: ${ }^{1} \mathbf{H}$ NMR $\left(\mathrm{CDCl}_{3}, 400 \mathrm{MHz}\right) \delta 1.12\left(\mathrm{t}, J=7.2 \mathrm{~Hz}, 3 \mathrm{H}, \mathrm{CH}_{3}\right), 1.73(\mathrm{~m}, 1 \mathrm{H})$, $1.78(\mathrm{~m}, 1 \mathrm{H}), 1.84-1.95(\mathrm{~m}, 2 \mathrm{H}), 1.98-2.01(\mathrm{~m}, 2 \mathrm{H}), 2.10-2.16(\mathrm{~m}, 2 \mathrm{H}), 2.53-2.42(\mathrm{~m}, 2 \mathrm{H}), 3.43(\mathrm{~m}$, $\left.1 \mathrm{H}, \mathrm{H}_{\mathrm{c}}\right), 3.54\left(\mathrm{dd}, J=4.5,9.0 \mathrm{~Hz}, 1 \mathrm{H}, \mathrm{H}_{\mathrm{b}}\right), 3.77-3.90\left(\mathrm{~m}, 2 \mathrm{H}, \mathrm{SCH}_{2}\right), 4.26$ (bs, $\left.1 \mathrm{H}, \mathrm{SCH}_{\mathrm{e}}\right) .{ }^{13} \mathbf{C} \mathbf{~ N M R}$

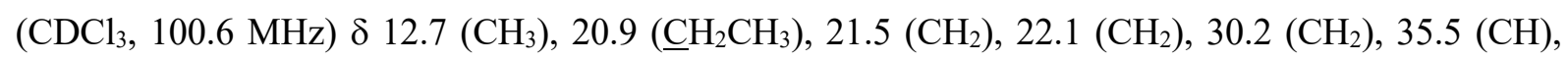
$39.1\left(\mathrm{CH}_{2}\right), 39.6(\mathrm{CH}), 44.7\left(\mathrm{CH}_{\mathrm{b}}\right), 45.0\left(\mathrm{CH}_{\mathrm{c}}\right), 49.7\left(\mathrm{SCH}_{\mathrm{e}}\right), 136.1(\mathrm{C}=\mathrm{C}), 140.2(\mathrm{C}=\mathrm{C}), 170.9(\mathrm{C}=\mathrm{O})$, $171.4(\mathrm{C}=\mathrm{O})$. HRMS (ESI/Q-TOF) $\mathbf{m} / \mathbf{z}$ : $\left[\mathrm{M}+\mathrm{H}^{+}\right]$calculated for $\mathrm{C}_{15} \mathrm{H}_{18} \mathrm{O}_{3} \mathrm{~S}$ 279.1049, found 279.1057 .

Minor stereoisomer (characteristic signals different from 4a): ${ }^{1} \mathbf{H}$ NMR $\left(\mathrm{CDCl}_{3}, 400 \mathrm{MHz}\right), \delta 1.02$ (t, $\left.J=7.2 \mathrm{~Hz}, 3 \mathrm{H}, \mathrm{CH}_{3}\right), 4.00$ (bs, $\left.1 \mathrm{H}, \mathrm{SCH}_{\mathrm{e}}\right) .{ }^{13} \mathbf{C} \mathbf{N M R}\left(\mathrm{CDCl}_{3}, 100.6 \mathrm{MHz}\right) \delta 12.4\left(\mathrm{CH}_{3}\right), 23.4$ $\left(\underline{\mathrm{CH}}_{2} \mathrm{CH}_{3}\right), 26.3\left(\mathrm{CH}_{2}\right), 29.8\left(\mathrm{CH}_{2}\right), 31.3\left(\mathrm{CH}_{2}\right), 34.1(\mathrm{CH}), 36.1\left(\mathrm{CH}_{2}\right), 38.2(\mathrm{CH}), 39.7(\mathrm{CH}), 43.3$ $(\mathrm{CH}), 55.5(\mathrm{CH}), 131.0(\mathrm{C}=\mathrm{C}), 137.0(\mathrm{C}=\mathrm{C}), 170.70(\mathrm{C}=\mathrm{O}), 170.72(\mathrm{C}=\mathrm{O})$.

6-ethyl-8-phenyl-2,3,3a,5,6,6a,9a,9b-octahydrothieno[4',3',2':4,5]naphtho[1,2-c]pyrrole-7,9(1H,8H)dione (5aA). A mixture of diene 3a (43 mg, $0.24 \mathrm{mmol}, 1.1$ equiv) and N-phenylmaleimide D2 (35 $\mathrm{mg}, 0.2 \mathrm{mmol}, 1$ equiv) was stirred $2 \mathrm{~h}$ at $40{ }^{\circ} \mathrm{C}$ in dichloromethane $(0.5 \mathrm{~mL})$. The product $5 \mathbf{a A}$ was then purified by flash chromatography (heptane/ethyl acetate 9/1) and obtained as single diastereomer, as a white paste $(65 \mathrm{mg}, 93 \%)$.

${ }^{1} \mathbf{H}$ NMR $\left(\mathrm{CDCl}_{3}, 400 \mathrm{MHz}\right) \delta 1.16\left(\mathrm{t}, J=7.3 \mathrm{~Hz}, 3 \mathrm{H}, \mathrm{CH}_{3}\right), 1.58-1.68(\mathrm{~m}, 2 \mathrm{H}), 1.77-1.96(\mathrm{~m}, 3 \mathrm{H})$, $1.99(\mathrm{~m}, 1 \mathrm{H}), 2.18(\mathrm{~m}, 1 \mathrm{H}), 2.27(\mathrm{~m}, 1 \mathrm{H}), 2.38-2.49(\mathrm{~m}, 2 \mathrm{H}), 3.31(\mathrm{t}, J=8.1 \mathrm{~Hz}, 1 \mathrm{H}), 3.42(\mathrm{dd}, J=$ 4.6, 8.1 Hz, 1H), 3.80-3.90 (m, 2H, $\left.\mathrm{SCH}_{2}\right), 4.27$ (bs, 1H, SCH), 7.12-7.14 (m, 2H), $7.38(\mathrm{~m}, 1 \mathrm{H}), 7.42-$ $7.46(\mathrm{~m}, 2 \mathrm{H}) .{ }^{13} \mathrm{C} \mathbf{~ N M R}\left(\mathrm{CDCl}_{3}, 100.6 \mathrm{MHz}\right) \delta 13.1\left(\mathrm{CH}_{3}\right), 21.3\left(\underline{\mathrm{CH}}_{2} \mathrm{CH}_{3}\right), 21.9\left(\mathrm{CH}_{2}\right), 22.5\left(\mathrm{CH}_{2}\right)$, $30.5(\mathrm{CH}), 36.5\left(\mathrm{CH}_{2}\right), 39.2\left(\mathrm{SCH}_{2}\right), 40.4(\mathrm{CH}), 44.2(\mathrm{CH}), 44.7(\mathrm{CH}), 49.8(\mathrm{SCH}), 126.8(2 \times \mathrm{CH})$, $128.8(\mathrm{CH}), 129.3(2 \times \mathrm{xH}), 132.0(\mathrm{Cq}), 135.8(\mathrm{C}=\mathrm{C}), 139.9(\mathrm{C}=\mathrm{C}), 176.1(\mathrm{C}=\mathrm{O}), 176.7(\mathrm{C}=\mathrm{O})$. HRMS (ESI/Q-TOF) m/z: $\left[\mathrm{M}+\mathrm{H}^{+}\right]$calculated for $\mathrm{C}_{21} \mathrm{H}_{23} \mathrm{NO}_{2} \mathrm{~S} 354.1522$, found 354.1530.

dimethyl 3-ethyl-3,5a,6, 7,8,8a-hexahydro-2H-naphtho[1,8-bc]thiophene-4,5-dicarboxylate (6a)

A mixture of diene 3a (50 mg, $0.28 \mathrm{mmol}, 1$ equiv) and dimethyl acetylenedicarboxylate $\mathbf{D 3}$ (60 mg, $0.42 \mathrm{mmol}, 1.5$ equiv) was stirred overnight at $80^{\circ} \mathrm{C}$ in toluene $(3 \mathrm{~mL})$. The product was then purified by flash chromatography (heptane/ethyl acetate 9/1) and obtained as an inseparable mixture of two diastereomers in 10/3 ratio, as a colorless oil (57 mg, 65\%).

Major stereoisomer 6aA: ${ }^{1} \mathbf{H}$ NMR $\left(\mathrm{CDCl}_{3}, 400 \mathrm{MHz}\right) \delta 0.63\left(\mathrm{t}, J=7.5 \mathrm{~Hz}, 3 \mathrm{H}, \mathrm{CH}_{3}\right), 1.39(\mathrm{~m}, 1 \mathrm{H})$, 1.52-1.60 (m, 2H), 1.63-1.73 (m, 2H), 1.78-1.93 (m, 2H), $2.19(\mathrm{~m}, 1 \mathrm{H}), 3.18(\mathrm{~m}, 1 \mathrm{H}), 3.36(\mathrm{~m}, 1 \mathrm{H})$, $3.54(\mathrm{~m}, 1 \mathrm{H}), 3.72\left(\mathrm{~s}, 3 \mathrm{H}, \mathrm{OCH}_{3}\right), 3.74\left(\mathrm{~s}, 3 \mathrm{H}, \mathrm{OCH}_{3}\right), 3.78(\mathrm{~m}, 1 \mathrm{H}), 4.18(\mathrm{~m}, 1 \mathrm{H}, \mathrm{SCH}) .{ }^{13} \mathbf{C} \mathbf{~ N M R}$ $\left(\mathrm{CDCl}_{3}, 100.6 \mathrm{MHz}\right) \delta 8.6\left(\mathrm{CH}_{3}\right), 21.0\left(\mathrm{CH}_{2}\right), 23.2\left(\underline{\mathrm{CH}}_{2} \mathrm{CH}_{3}\right), 23.5\left(\mathrm{CH}_{2}\right), 25.9\left(\mathrm{CH}_{2}\right), 36.3(\mathrm{CH})$, 
$38.8\left(\mathrm{SCH}_{2}\right), 39.2(\mathrm{CH}), 49.8(\mathrm{SCH}), 52.1\left(2 \mathrm{xOCH}_{3}\right), 129.7(\mathrm{C}=\mathrm{C}), 135.1(\mathrm{C}=\mathrm{C}), 138.6(\mathrm{C}=\mathrm{C}), 139.5$ $(\mathrm{C}=\mathrm{C}), 167.8(\mathrm{C}=\mathrm{O}), 168.5(\mathrm{C}=\mathrm{O})$.

Minor stereoisomer 6aB: ${ }^{1} \mathbf{H}$ NMR $\left(\mathrm{CDCl}_{3}, 400 \mathrm{MHz}\right)$ characteristic signals different from 6aA: $\delta$ $0.70\left(\mathrm{t}, J=7.5 \mathrm{~Hz}, 3 \mathrm{H}, \mathrm{CH}_{3}\right), 3.97$ (m, $\left.1 \mathrm{H}, \mathrm{SCH}\right) .{ }^{13} \mathbf{C ~ N M R}\left(\mathrm{CDCl}_{3}, 100.6 \mathrm{MHz}\right) \delta 8.5,22.9,25.8$, $33.7,39.5,39.6,39.9,52.2,54.9,127.1,136.6,137.1,137.8,167.8,168.5$.

6aA/B: HRMS (ESI/Q-TOF) m/z: $\left[\mathrm{M}+\mathrm{H}^{+}\right]$calculated for $\mathrm{C}_{17} \mathrm{H}_{23} \mathrm{O}_{4} \mathrm{~S} 323.1312$, found 323.1308 .

6-ethyl-9-phenyl-1,2,3,3a,6,11a-hexahydro-5H,8H-thieno[4,3,2-de][1,2,4]triazolo[1,2-a]cinnoline8,10(9H)-dione (7aA) and 6-ethyl-9-phenyl-1,2,3,11a-tetrahydro-6H,8H-thieno[4,3,2de][1,2,4]triazolo[1,2-a]cinnoline-8,10(9H)-dione (8a)

A mixture of diene 3a (23 mg, $0.13 \mathrm{mmol}, 1$ equiv) and 4-phenyl-3H-1,2,4-triazole-3,5(4H)-dione $\mathbf{D 4}$ (43 mg, $0.26 \mathrm{mmol}, 2$ equiv) was stirred $1 \mathrm{~h}$, at room temperature, in dichloromethane ( $0.5 \mathrm{~mL}$ ). The product was then purified by flash chromatography (heptane/ethyl acetate 9/1) and obtained as a mixture of 7aA and 8a in 1:2 ratio. Each one was isolated as a single diastereomers: 7aA as an amorphous white solid (11 mg, 22\%) of and 8a as a viscous oil (23 mg, 45\%).

Product 7aA: ${ }^{1} \mathbf{H}$ NMR $\left(\mathrm{CDCl}_{3}, 400 \mathrm{MHz}\right) \delta 0.94\left(\mathrm{t}, J=7.7,3 \mathrm{H}, \mathrm{CH}_{3}\right), 1.47-1.58(\mathrm{~m}, 4 \mathrm{H}), 1.74(\mathrm{~m}$, $1 \mathrm{H}), 1.95(\mathrm{~m}, 1 \mathrm{H}), 2.13-2.0(\mathrm{~m}, 2 \mathrm{H}), 2.96(\mathrm{~m}, 1 \mathrm{H}), 3.85\left(\mathrm{mAB}, 2 \mathrm{H}, \mathrm{CH}_{2}\right), 4.19(\mathrm{~m}, 1 \mathrm{H}), 4.21(\mathrm{~m}, 1 \mathrm{H})$, $4.63(\mathrm{bs}, 1 \mathrm{H}), 7.32-7.36(\mathrm{~m}, 2 \mathrm{H}), 7.42-7.51(\mathrm{~m}, 3 \mathrm{H}) .{ }^{13} \mathbf{C ~ N M R}\left(\mathrm{CDCl}_{3}, 100.6 \mathrm{MHz}\right) \delta 9.4\left(\mathrm{CH}_{3}\right), 23.5$ $\left(\mathrm{CH}_{2}\right), 24.8\left(\mathrm{CH}_{2}\right), 33.3\left(\mathrm{CH}_{2}\right), 38.0\left(\mathrm{CH}_{2}\right), 38.3\left(\mathrm{CH}_{2}\right), 53.3(\mathrm{CH}), 54.6(\mathrm{CH}), 57.3(\mathrm{CH}), 125.6(\mathrm{CH})$, $128.1(\mathrm{Cq}), 128.2(\mathrm{CH}), 129.2(\mathrm{CH}), 131.4(\mathrm{Cq}), 135.1(\mathrm{Cq}), 149.5(\mathrm{C}=\mathrm{O}), 153.4(\mathrm{C}=\mathrm{O})$. HRMS (ESI/Q-TOF) m/z: [M+H $\left.{ }^{+}\right]$calculated for $\mathrm{C}_{23} \mathrm{H}_{22} \mathrm{~N}_{3} \mathrm{O}_{2} \mathrm{~S}$ 404.1433, found 404.1449.

Product 8a: ${ }^{1} \mathbf{H}$ NMR $\left(\mathrm{CDCl}_{3}, 400 \mathrm{MHz}\right) \delta 0.88\left(\mathrm{t}, J=7.7,3 \mathrm{H}, \mathrm{CH}_{3}\right), 1.81-1.91(\mathrm{~m}, 3 \mathrm{H}), 2.15(\mathrm{~m}$, $1 \mathrm{H}), 2.22(\mathrm{~m}, 1 \mathrm{H}), 2.75-2.98(\mathrm{~m}, 2 \mathrm{H}), 3.05(\mathrm{~m}, 1 \mathrm{H}), 4.45(\mathrm{~m}, 1 \mathrm{H}), 5.31(\mathrm{~m}, 1 \mathrm{H}), 7.32-7.36(\mathrm{~m}, 2 \mathrm{H})$, $6.90(\mathrm{~s}, 1 \mathrm{H}), 7.25-7.28(\mathrm{~m}, 1 \mathrm{H}), 7.46-7.54(\mathrm{~m}, 4 \mathrm{H}) .{ }^{13} \mathbf{C} \mathbf{~ N M R}\left(\mathrm{CDCl}_{3}, 100.6 \mathrm{MHz}\right) \delta 9.5\left(\mathrm{CH}_{3}\right), 21.7$ $\left(\mathrm{CH}_{2}\right), 24.0\left(\mathrm{CH}_{2}\right), 27.1\left(\mathrm{CH}_{2}\right), 28.5\left(\mathrm{CH}_{2}\right), 56.0(\mathrm{CH}), 59.5(\mathrm{CH}), 117.2(\mathrm{CH}), 125.6(2 \mathrm{xCH}), 128.3$ (CH), $129.2(2 \times C H), 131.1(\mathrm{Cq}), 131.4(\mathrm{Cq}), 136.1(\mathrm{Cq}), 151.1(\mathrm{C}=\mathrm{O}), 155.8(\mathrm{C}=\mathrm{O})$. HRMS (ESI/QTOF) $\mathbf{m} / \mathbf{z}:\left[\mathrm{M}+\mathrm{H}^{+}\right]$calculated for $\mathrm{C}_{23} \mathrm{H}_{19} \mathrm{~N}_{3} \mathrm{O}_{2} \mathrm{~S} 401.1198$, found 401.1204 .

Cycloaddition between diene (3a) and dithioester (D5). 2-(Methylsulfanyl)carbothioylpyridine D5 (47 mg, $0.28 \mathrm{mmol}, 1$ equiv) and boron trifluoride diethyl etherate $(0.035 \mathrm{~mL}, 0.28 \mathrm{mmol}, 1$ equiv) were mixed in dichloromethane $(0.6 \mathrm{~mL})$. After $5 \mathrm{~min}$, diene $\mathbf{3 a}(54 \mathrm{mg}, 0.3 \mathrm{mmol}, 1.1$ equiv) was added in dichloromethane $(0.2 \mathrm{~mL})$. Then the reaction mixture was stirred $1 \mathrm{~h}$ at $40{ }^{\circ} \mathrm{C}$ in DCM. The mixture was washed with a saturated solution of $\mathrm{NaHCO}_{3}$ and the product was extracted with dichloromethane. The organic layers were then dried with $\mathrm{MgSO}_{4}$ and evaporated under vacuum. After purification by flash chromatography (heptane/ethyl acetate 9/1) the product was obtained as an inseparable mixture of two cycloadducts (ratio 3:1), as an orange oil (70 $\mathrm{mg}, 72 \%$ ). The structures have been not assigned. 
Major cycloadduct 10a: ${ }^{1} \mathbf{H}$ NMR $\left(\mathrm{CDCl}_{3}, 400 \mathrm{MHz}\right) \delta 1.02(\mathrm{~m}, 1 \mathrm{H}), 1.13\left(\mathrm{t}, J=7.1 \mathrm{~Hz}, 3 \mathrm{H}, \mathrm{CH}_{3}\right)$, $1.37(\mathrm{~m}, 1 \mathrm{H}), 1.47(\mathrm{~m}, 1 \mathrm{H}), 1.54(\mathrm{~m}, 1 \mathrm{H}), 1.70(\mathrm{~m}, 1 \mathrm{H}), 1.80$ (s, 3H, SMe), 1.85 (m, 1H), 1.99 (m, 1H), $2.10(\mathrm{~m}, 1 \mathrm{H}), 2.69(\mathrm{~m}, 1 \mathrm{H}), 3.66-3.72(\mathrm{~m}, 2 \mathrm{H}), 3.97-4.02(\mathrm{~m}, 2 \mathrm{H}), 7.17\left(\mathrm{~m}, 1 \mathrm{H}, \mathrm{H}_{\mathrm{Py}}\right), 7.69-7.73$ $\left(\mathrm{m}, 2 \mathrm{H}, \mathrm{H}_{\mathrm{Py}}\right), 8.56\left(\mathrm{~m}, 1 \mathrm{H}, \mathrm{H}_{\mathrm{Py}}\right) .{ }^{13} \mathbf{C} \mathbf{N M R}\left(\mathrm{CDCl}_{3}, 100.6 \mathrm{MHz}\right) \delta 12.0\left(\mathrm{CH}_{3}\right), 13.1(\mathrm{SMe}), 24.5$ $\left(\underline{\mathrm{CH}}_{2} \mathrm{CH}_{3}\right), 26.2\left(\mathrm{CH}_{2}\right), 31.3\left(\mathrm{CH}_{2}\right), 39.1\left(\mathrm{SCH}_{2}\right), 40.9\left(\mathrm{CH}_{2}\right), 41.9(\mathrm{CHEt}), 50.8(\mathrm{CHS}), 56.8(\mathrm{CH})$, $68.8(\mathrm{Cq}), 122.3\left(\mathrm{CH}_{\text {Py }}\right), 122.4\left(\mathrm{CH}_{\text {Py }}\right), 127.9(\mathrm{C}=\mathrm{C}), 136.7\left(\mathrm{CH}_{\text {Py }}\right), 141.0(\mathrm{C}=\mathrm{C}), 148.3\left(\mathrm{CH}_{\text {Py }}\right), 161.1$ (Cq). HRMS (ESI/Q-TOF) m/z: $\left[\mathrm{M}+\mathrm{H}^{+}\right]$calculated for $\mathrm{C}_{18} \mathrm{H}_{24} \mathrm{NS}_{3} 350.1065$, found 350.1058 .

\section{Cycloadditions of diene (3b)}

6-phenyl-1,2,3,3a,6,6a,9a,9b-octahydro-5H-thieno[4',3',2':4,5]naphtho[1,2-c]furan-7,9-dione (4bA) A mixture of diene $\mathbf{3 b}(21 \mathrm{mg}, 0.09 \mathrm{mmol}, 1.1$ equiv) and maleic anhydride $\mathbf{D 1}(8 \mathrm{mg}, 0.08 \mathrm{mmol}, 1$ equiv) was stirred $2 \mathrm{~h}$ at $40{ }^{\circ} \mathrm{C}$ in dichloromethane $(1 \mathrm{~mL})$. The product $4 \mathbf{b A}$ was then purified by trituration in pentane and obtained as single diastereomer, as a white solid with $\mathrm{mp}=137^{\circ} \mathrm{C}(13 \mathrm{mg}$, $50 \%)$.

${ }^{1} \mathbf{H}$ NMR $\left(\mathrm{CDCl}_{3}, 500 \mathrm{MHz}\right) \delta 1.63(\mathrm{~m}, 1 \mathrm{H}), 1.75(\mathrm{~m}, 1 \mathrm{H}), 1.89(\mathrm{~m}, 1 \mathrm{H}), 2.00(\mathrm{~m}, 1 \mathrm{H}), 2.15-2.20(\mathrm{~m}$, $2 \mathrm{H}), 2.56\left(\mathrm{~m}, 1 \mathrm{H}, \mathrm{H}_{\mathrm{d}}\right), 3.29(\mathrm{~m}, 1 \mathrm{H}, \mathrm{SC} \underline{\mathrm{H}}), 3.49\left(\mathrm{dd}, J=8.7,6.6 \mathrm{~Hz}, 1 \mathrm{H}, \mathrm{H}_{\mathrm{c}}\right), 3.68(\mathrm{dd}, J=8.7,7.7$ $\left.\mathrm{Hz}, 1 \mathrm{H}, \mathrm{H}_{\mathrm{b}}\right), 3.83\left(\mathrm{~m}, 1 \mathrm{H}, \mathrm{H}_{\mathrm{a}}\right), 3.88(\mathrm{~m}, 1 \mathrm{H}, \mathrm{SCH} \underline{\mathrm{H}}), 4.41\left(\mathrm{~m}, 1 \mathrm{H}, \mathrm{SCH}_{\mathrm{e}}\right)$, 7.27-7.32 (m, 2H), 7.33$7.35(\mathrm{~m}, 3 \mathrm{H}) .{ }^{13} \mathbf{C}$ NMR $\left(\mathrm{CDCl}_{3}, 125.7 \mathrm{MHz}\right) \delta 20.7\left(\mathrm{CH}_{2}\right), 21.7\left(\mathrm{CH}_{2}\right), 29.4\left(\mathrm{CH}_{2}\right), 34.4\left(\mathrm{CH}_{\mathrm{d}}\right), 40.6$ $\left(\mathrm{SCH}_{2}\right), 43.9\left(\mathrm{CH}_{\mathrm{a}}\right), 45.7\left(\mathrm{CH}_{\mathrm{c}}\right), 48.4\left(\mathrm{CH}_{\mathrm{b}}\right), 50.0\left(\mathrm{SCH}_{\mathrm{e}}\right), 128.2(\mathrm{Cq}), 128.7(2 \mathrm{xCH}), 129.9(2 \times \mathrm{XH})$, $133.1(\mathrm{Cq}), 136.5(\mathrm{Cq}), 142.4(\mathrm{Cq}), 170.2\left(\mathrm{CH}_{\mathrm{c}} \underline{\mathrm{C}}=\mathrm{O}\right), 170.8\left(\mathrm{CH}_{\mathrm{b}} \underline{\mathrm{C}}=\mathrm{O}\right) . \mathbf{H R M S}(\mathbf{E S I} / \mathbf{Q}-\mathbf{T O F}) \mathbf{m} / \mathbf{z}$ : $\left[\mathrm{M}+\mathrm{H}^{+}\right]$calculated for $\mathrm{C}_{19} \mathrm{H}_{18} \mathrm{O}_{3} \mathrm{~S} 327.1049$, found 327.1037 .

6,8-diphenyl-2,3,3a,5,6,6a,9a,9b-octahydrothieno[4',3',2':4,5]naptho[1,2-c]pyrrole-7,9(1H,8H)-dione $(5 b A)$

A mixture of diene $\mathbf{3 b}$ (30 mg, $0.13 \mathrm{mmol}, 1.1$ equiv) and N-phenylmaleimide D2 (15 mg, $0.09 \mathrm{mmol}$, 1 equiv) was stirred $2 \mathrm{~h}$ at $40{ }^{\circ} \mathrm{C}$ in dichloromethane $(1 \mathrm{~mL})$. The product $5 \mathbf{b A}$ was then purified by flash chromatography (heptane/ethyl acetate 9/1) and obtained as a single diastereomer, as an amorphous white solid (35 mg, 97\%).

${ }^{1} \mathbf{H}$ NMR $\left(\mathrm{CDCl}_{3}, 400 \mathrm{MHz}\right) \delta$ 1.63-1.83 (m, 2H), 1.96-2.02 (m, 2H), 2.11-2.22 (m, 2H), $2.66(\mathrm{~m}$, $1 \mathrm{H}), 3.36-3.42\left(\mathrm{~m}, 2 \mathrm{H}, \mathrm{H}_{\mathrm{b}}\right.$ and $\left.\mathrm{SC} \underline{H} \mathrm{H}\right), 3.62\left(\mathrm{t}, J=7.4 \mathrm{~Hz}, 1 \mathrm{H}, \mathrm{H}_{\mathrm{c}}\right), 3.87-3.92\left(\mathrm{~m}, 2 \mathrm{H}, \mathrm{H}_{\mathrm{a}}\right.$ and $\left.\mathrm{SCH} \underline{\mathrm{H}}\right)$, $4.41\left(\mathrm{~m}, 1 \mathrm{H}, \mathrm{SCH}_{\mathrm{e}}\right), 6.99\left(\mathrm{~d}, J=8.0 \mathrm{~Hz}, 2 \mathrm{H}, \mathrm{H}_{\mathrm{ar}}\right), 7.28-7.34\left(\mathrm{~m}, 6 \mathrm{H}, \mathrm{H}_{\mathrm{ar}}\right), 7.38\left(\mathrm{t}, J=7.4 \mathrm{~Hz}, 2 \mathrm{H}, \mathrm{H}_{\mathrm{ar}}\right)$. ${ }^{13} \mathbf{C ~ N M R}\left(\mathrm{CDCl}_{3}, 100.6 \mathrm{MHz}\right) \delta 21.1\left(\mathrm{CH}_{2}\right), 22.3\left(\mathrm{CH}_{2}\right), 29.6\left(\mathrm{CH}_{2}\right), 35.3\left(\mathrm{CH}_{\mathrm{d}}\right) 40.6\left(\mathrm{SCH}_{2}\right), 44.7$ $\left(\mathrm{CH}_{\mathrm{a}}\right), 44.8\left(\mathrm{CH}_{\mathrm{b}}\right), 47.7\left(\mathrm{CH}_{\mathrm{c}}\right), 50.2\left(\mathrm{SCH}_{\mathrm{e}}\right), 126.4(2 \mathrm{xCH}), 127.7(\mathrm{CH}), 128.5(2 \mathrm{xCH}), 128.6(\mathrm{CH})$, $129.2(2 \mathrm{xCH}), 130.4(2 \mathrm{xCH}), 131.8(\mathrm{Cq}), 133.2(\mathrm{C}=\mathrm{C}), 137.7(\mathrm{Cq}), 141.7(\mathrm{C}=\mathrm{C}), 175.7(\mathrm{C}=\mathrm{O}), 175.9$ $(\mathrm{C}=\mathrm{O})$. HRMS (ESI/Q-TOF) m/z: $\left[\mathrm{M}+\mathrm{H}^{+}\right]$calculated for $\mathrm{C}_{25} \mathrm{H}_{23} \mathrm{NO}_{2} \mathrm{~S} 402.1528$, found 402.1529 . 6,9-diphenyl-1,2,3,3a,6,11a-hexahydro-5H,8H-thieno[4,3,2-de][1,2,4]triazolo[1,2-a]cinnoline8,10(9H)-dione (7bA) and 6,9-diphenyl-1,2,3,11a-tetrahydro-6H,8H-thieno [4,3,2de][1,2,4]triazolo[1,2-a]cinnoline-8,10(9H)-dione (8b) 
A mixture of diene $\mathbf{3 b}$ (30 mg, $0.13 \mathrm{mmol}, 1$ equiv) and 4-phenyl-3H-1,2,4-triazole-3,5(4H)-dione $\mathbf{D 4}$ (46 mg, $0.26 \mathrm{mmol}, 2$ equiv) was stirred $30 \mathrm{~min}$, at room temperature, in dichloromethane ( $0.5 \mathrm{~mL}$ ). The product was then purified by flash chromatography (heptane/ethyl acetate 9/1) and obtained as a mixture of $\mathbf{7 b A}$ and $\mathbf{8 b}$ in 1:1 ratio. Each one was isolated as a single diastereomer: $\mathbf{7 b \mathbf { A }}$ as a viscous oil (11 mg, 22\%) and $\mathbf{8 b}$ as a white solid with $\mathrm{mp}=184{ }^{\circ} \mathrm{C}(13 \mathrm{mg}, 26 \%)$.

(7bA): ${ }^{1} \mathbf{H}$ NMR $\left(\mathrm{CDCl}_{3}, 400 \mathrm{MHz}\right) \delta 1.69(\mathrm{~m}, 1 \mathrm{H}), 1.94(\mathrm{~m}, 1 \mathrm{H}), 1.98-2.05(\mathrm{~m}, 2 \mathrm{H}), 2.10(\mathrm{~m}, 1 \mathrm{H})$, $3.05(\mathrm{~m}, 1 \mathrm{H}), 3.36(\mathrm{~m}, 1 \mathrm{H}, \mathrm{SC} \underline{H} \mathrm{H}), 3.41(\mathrm{~m}, 1 \mathrm{H}, \mathrm{SCH} \underline{\mathrm{H}}), 4.34(\mathrm{~m}, 1 \mathrm{H}), 4.45(\mathrm{~m}, 1 \mathrm{H}), 5.63(\mathrm{~s}, 1 \mathrm{H})$, 7.35-7.39 (m, 10H). ${ }^{13} \mathbf{C}$ NMR $\left(\mathrm{CDCl}_{3}, 100.6 \mathrm{MHz}\right) \delta 19.7\left(\mathrm{CH}_{2}\right), 22.3\left(\mathrm{CH}_{2}\right), 25.1\left(\mathrm{CH}_{2}\right), 38.3\left(\mathrm{CH}_{2}\right)$ $49.2(\mathrm{CH}), 57.1(\mathrm{CH}), 58.4(\mathrm{CH}), 125.6(2 \mathrm{xCH}), 128.0(\mathrm{CH}), 128.2(\mathrm{CH}), 129.8(2 \times \mathrm{CH}), 130.2(\mathrm{Cq})$, $131.2(\mathrm{Cq}), 136.2(\mathrm{Cq}), 137.8(\mathrm{Cq}), 149.9(\mathrm{C}=\mathrm{O}), 154.9(\mathrm{C}=\mathrm{O})$. HRMS (ESI/Q-TOF) m/z: [M+H $\left.{ }^{+}\right]$ calculated for $\mathrm{C}_{23} \mathrm{H}_{22} \mathrm{~N}_{3} \mathrm{O}_{2} \mathrm{~S} 404.1433$, found 404.1449.

(8b): ${ }^{1} \mathbf{H}$ NMR $\left(\mathrm{CDCl}_{3}, 400 \mathrm{MHz}\right) \delta$ 1.94-1.99 (m, 2H), $2.28(\mathrm{~m}, 1 \mathrm{H}), 2.90-2.95(\mathrm{~m}, 2 \mathrm{H}), 3.20$ (m, 1H), 4.61 (m, 1H, CH), 6.27 (d, $J=1.1 \mathrm{~Hz}, 1 \mathrm{H}, \mathrm{NCHPh}), 6.74$ (d, $J=1.1 \mathrm{~Hz}, 1 \mathrm{H}, \mathrm{SCH}), 7.24-7.38$ (m, 10H). ${ }^{13} \mathbf{C}$ NMR $\left(\mathrm{CDCl}_{3}, 100.6 \mathrm{MHz}\right) \delta 21.7\left(\mathrm{CH}_{2}\right), 24.1\left(\mathrm{CH}_{2}\right), 27.2\left(\mathrm{CH}_{2}\right), 58.9(\mathrm{CH}), 59.6$ $(\mathrm{CH}), 119.6(\mathrm{SCH}), 125.6(2 \mathrm{xCH}), 128.2(2 \mathrm{xCH}), 128.3(\mathrm{CH}), 128.6(\mathrm{Cq}), 128.8(2 \mathrm{xCH}), 129.2$ (2xCH), $131.3(\mathrm{Cq}), 133.0(\mathrm{Cq}), 136.3(\mathrm{Cq}), 140.3(\mathrm{Cq}), 151.3(\mathrm{C}=\mathrm{O}), 155.6(\mathrm{C}=\mathrm{O})$. HRMS (ESI/QTOF) $\mathbf{m} / \mathbf{z}:\left[\mathrm{M}+\mathrm{H}^{+}\right]$calculated for $\mathrm{C}_{23} \mathrm{H}_{19} \mathrm{~N}_{3} \mathrm{O}_{2} \mathrm{~S} 401.1198$, found 401.1204 .

2-(4-(methylthio)-3-phenyl-2,3,4,5a,6, 7,8,8a-octahydrothieno[4,3,2-de]thiochromen-4-yl)pyridine (10b)

2-(Methylsulfanyl)carbothioylpyridine $\mathbf{D 5}(17 \mathrm{mg}, 0.1 \mathrm{mmol}, 1$ equiv) and boron trifluoride diethyl etherate $(0.0127 \mathrm{~mL}, 0.1 \mathrm{mmol}, 1$ equiv) were mixed in dichloromethane $(0.2 \mathrm{~mL})$. After $5 \mathrm{~min}$, diene 3b $(25 \mathrm{mg}, 0.11 \mathrm{mmol}, 1.1$ equiv) was added in dichloromethane $(0.2 \mathrm{~mL})$. Then the reaction mixture was stirred $1 \mathrm{~h}$ at $40{ }^{\circ} \mathrm{C}$ in $\mathrm{DCM}$. The mixture was washed with a saturated solution of $\mathrm{NaHCO}_{3}$ and the product was extracted with dichloromethane. The organic layers were then dried with $\mathrm{MgSO}_{4}$ and evaporated under vacuum. After purification by flash chromatography (heptane/ethyl acetate 9/1) the product was obtained as an inseparable mixture of two cycloaducts (ratio 10:1), as a yellow oil (20 $\mathrm{mg}, 51 \%)$.

Major cycloadduct 10b: ${ }^{1} \mathrm{H}$ NMR $\left(\mathrm{CDCl}_{3}, 400 \mathrm{MHz}\right) \delta 1.71-2.11\left(\mathrm{~m}, 6 \mathrm{H},\left(\mathrm{CH}_{2}\right)_{3}\right), 1.83(\mathrm{~s}, 3 \mathrm{H}$, SMe), 3.26-3.38 (m, 2H, SCH$), 3.88\left(\mathrm{~s}, 1 \mathrm{H}, \mathrm{CH}_{\mathrm{a}}\right), 3.93-3.96\left(\mathrm{~m}, 1 \mathrm{H}, \mathrm{CH}_{\mathrm{d}}\right), 4.46\left(\mathrm{~m}, 1 \mathrm{H}, \mathrm{SCH}_{\mathrm{e}}\right), 6.09$ (m, 1H, $\left.\mathrm{H}_{\mathrm{Py}}\right), 6.95-7.10(5 \mathrm{H}), 7.15-7.19(\mathrm{~m}, 1 \mathrm{H}), 7.50$ (td, $\left.J=7.8,1.8 \mathrm{~Hz}, 1 \mathrm{H}, \mathrm{H}_{\mathrm{Py}}\right), 7.67$ (m, 1H, $\mathrm{H}_{\text {Py }}$ ), $8.22(\mathrm{dd}, J=5.0,1.8 \mathrm{~Hz}, 1 \mathrm{H}, \mathrm{H} \mathrm{Py}) .{ }^{13} \mathbf{C}$ NMR $\left(\mathrm{CDCl}_{3}, 100.6 \mathrm{MHz}\right) \delta 13.7(\mathrm{SMe}), 21.2\left(\mathrm{CH}_{2}\right), 22.8$ $\left(\mathrm{CH}_{2}\right), 27.2\left(\mathrm{CH}_{2}\right), 36.6\left(\mathrm{CH}_{\mathrm{d}}\right), 40.6\left(\mathrm{SCH}_{2}\right), 50.7\left(\mathrm{SCH}_{\mathrm{e}}\right), 55.6(\mathrm{CHPh}), 73.1(\mathrm{Cq}), 122.1\left(\mathrm{CH}_{\mathrm{Py}}\right)$, $123.2\left(\mathrm{CH}_{\mathrm{py}}\right), 127.0(\mathrm{CH}), 127.6(2 \mathrm{xCH}), 129.8(2 \mathrm{xCH}), 132.8(\mathrm{Cq}), 135.9\left(\mathrm{CH}_{\mathrm{Py}}\right), 137.7(\mathrm{Cq}), 138.5$ $(\mathrm{Cq}), 147.8\left(\mathrm{CH}_{\mathrm{Py}}\right), 159.8(\mathrm{Cq})$. The ionization to perform the mass analysis led to the oxidation of the compound with loose of two hydrogen atoms: HRMS (ESI/Q-TOF) m/z: $\left[\mathrm{M}+\mathrm{H}^{+}\right]$calculated for $\mathrm{C}_{22} \mathrm{H}_{22} \mathrm{NS}_{3} 396.0914$, found 396.0897 . 


\section{Cycloaddition of diene (3c)}

7-oxo-2a,3,4,5,5a,6,6a, 7,9,9a-decahydro-1H-thieno[2',3',4':8, 1]naphtho[2,3-c]furan-6-carboxylic acid (4'cA)

A mixture of diene $3 \mathbf{c}$ (30 mg, $0.16 \mathrm{mmol}, 1.1$ equiv) and maleic anhydride D1 (15 mg, $0.15 \mathrm{mmol}, 1$ equiv) was stirred $2.5 \mathrm{~h}$ at $40^{\circ} \mathrm{C}$ in dichloromethane $(1 \mathrm{~mL})$. The product 4 'c $\mathbf{A}$ was then purified by flash cromatography (heptane/ethyl acetate $8 / 2$ ) and obtained as a single diastereomer, as pale yellow solid with $\mathrm{mp}=151^{\circ} \mathrm{C}(38 \mathrm{mg}, 90 \%)$.

${ }^{1} \mathbf{H}$ NMR $\left(\mathrm{CDCl}_{3}, 400 \mathrm{MHz}\right) \delta 1.57-1.63(\mathrm{~m}, 2 \mathrm{H}), 1.72-1.78(\mathrm{~m}, 2 \mathrm{H}), 1.94(\mathrm{~m}, 1 \mathrm{H}), 2.10(\mathrm{~m}, 1 \mathrm{H}), 2.63$ (m, 1H), $3.11(\mathrm{~m}, 1 \mathrm{H}), 3.31-3.37(\mathrm{~m}, 2 \mathrm{H}), 3.45(\mathrm{~m}, 1 \mathrm{H}, \mathrm{SC} \underline{H H}), 3.75(\mathrm{~m}, 1 \mathrm{H}, \mathrm{SCH} \underline{\mathrm{H}}), 4.20(\mathrm{dd}, J=$ 9.6, 7.8 Hz, 1H, CH-O), 4.26 (m, 1H, SCH), 4.50 (dd, $J=8.6,7.8 \mathrm{~Hz}, 1 \mathrm{H}, \mathrm{CH}-\mathrm{O}) .{ }^{13} \mathbf{C} \mathbf{~ N M R}\left(\mathrm{CDCl}_{3}\right.$, $100.6 \mathrm{MHz}) \delta 20.6\left(\mathrm{CH}_{2}\right), 22.8\left(\mathrm{CH}_{2}\right), 28.2\left(\mathrm{CH}_{2}\right), 35.5(\mathrm{CH}), 36.9(\mathrm{CH}), 38.8\left(\mathrm{CH}_{2}\right), 41.5(\mathrm{CH}), 43.3$ $(\mathrm{CH}), 49.9(\mathrm{CH}), 71.0\left(\mathrm{CH}_{2} \mathrm{O}\right), 128.8(\mathrm{C}=\underline{\mathrm{C}}), 138.9(\mathrm{Cq}), 175.8(\mathrm{Cq}), 177.7(\mathrm{C}=\mathrm{O})$. HRMS (ESI/QTOF) m/z: $\left[\mathrm{M}+\mathrm{H}^{+}\right]$calculated for $\mathrm{C}_{14} \mathrm{H}_{17} \mathrm{O}_{4} \mathrm{~S} 281.0848$, found 281.0844 .

\section{Cycloadditions of diene (3d)}

7-methyl-1,2,3,3a,5,6,7,7a,10a,10b-decahydrobenzo[8,1]isothiochromeno[6,7-c]furan-8,10-dione (4dA)

A mixture of diene 3d (40 mg, $0.22 \mathrm{mmol}, 1.1$ equiv) and maleic anhydride D1 (25 mg, $0.22 \mathrm{mmol}, 1$ equiv) was stirred $2.5 \mathrm{~h}$ at $40{ }^{\circ} \mathrm{C}$ in dichloromethane $(0.3 \mathrm{~mL})$. The product $4 \mathbf{d d A}$ was then purified by flash chromatography (pentane/diethyl ether 8/2) and obtained as single diastereomer, as an amorphous white solid (29 mg, 47\%).

${ }^{1} \mathbf{H}$ NMR $\left(\mathrm{CDCl}_{3}, 500 \mathrm{MHz}\right) \delta 1.44\left(\mathrm{~d}, J=7.5 \mathrm{~Hz}, 3 \mathrm{H}, \mathrm{CH}_{3}\right), 1.49-1.55(\mathrm{~m}, 2 \mathrm{H}), 1.75(\mathrm{~m}, 1 \mathrm{H}), 1.85-$ $2.12(\mathrm{~m}, 2 \mathrm{H}), 2.15-2.40(\mathrm{~m}, 4 \mathrm{H}), 2.55-2.65(\mathrm{~m}, 3 \mathrm{H}), 3.18-3.25(\mathrm{~m}, 2 \mathrm{H}), 3.6(\mathrm{~m}, 1 \mathrm{H}, \mathrm{SCH}) .{ }^{13} \mathbf{C}$ NMR $\left(\mathrm{CDCl}_{3}, 125.7 \mathrm{MHz}\right) \delta 13.6\left(\mathrm{CH}_{3}\right), 20.3\left(\mathrm{CH}_{2}\right), 22.4\left(\mathrm{CH}_{2}\right), 25.5\left(\mathrm{CH}_{2}\right), 27.0\left(\mathrm{CH}_{2}\right), 27.7\left(\mathrm{CH}_{2}\right), 34.0$ $(\mathrm{CH}), 35.2(\mathrm{CH}), 37.0(\mathrm{CH}), 46.9(\mathrm{CH}), 45.7(\mathrm{CH}), 134.0(\mathrm{Cq}), 135.3(\mathrm{Cq}), 171.7(2 \times \mathrm{C}=\mathrm{O})$. HRMS (APCI/Q-TOF) m/z: $\left[\mathrm{M}+\mathrm{H}^{+}\right]$calculated for $\mathrm{C}_{15} \mathrm{H}_{18} \mathrm{O}_{3} \mathrm{~S} 279.1049$, found 279.1037 .

dimethyl-4-methyl-2,3,4,6a, 7,8,9,9a-octahydrobenzo[de]thiochromene-5, 6-dicarboxylate (6dA/6dB) A mixture of diene 3d (50 mg, $0.28 \mathrm{mmol}, 1$ equiv) and dimethyl acetylenedicarboxylate $\mathbf{D 3}$ (59 mg, $0.42 \mathrm{mmol}, 1.5$ equiv) was stirred overnight at $80{ }^{\circ} \mathrm{C}$ in toluene $(1 \mathrm{~mL})$. The resulted product was obtained as an inseparable mixture of two diastereomers in 2/1 ratio, as a colorless oil (49 $\mathrm{mg}, 54 \%$ ) and purified by flash chromatography (heptane/ethyl acetate 9/1). A small fraction enriched in minor isomer $\mathbf{6 d B}$ was isolated (ratio 2/10).

Major stereoisomer 6dA: ${ }^{1} \mathbf{H}$ NMR $\left(\mathrm{CDCl}_{3}, 400 \mathrm{MHz}\right) \delta 1.21\left(\mathrm{~d}, J=7.1 \mathrm{~Hz}, 3 \mathrm{H}, \mathrm{CH}_{3}\right), 1.55-2.1(\mathrm{~m}$, $4 \mathrm{H}), 2.15(\mathrm{~m}, 2 \mathrm{H}), 2.43(\mathrm{~m}, 2 \mathrm{H}), 2.95(\mathrm{~m}, 2 \mathrm{H}), 3.15(\mathrm{~m}, 2 \mathrm{H}), 3.30(\mathrm{~m}, 1 \mathrm{H}), 3.76\left(6 \mathrm{H}, 2 \mathrm{xOCH}_{3}\right) .{ }^{13} \mathbf{C}$ NMR $\left(\mathrm{CDCl}_{3}, 100.6 \mathrm{MHz}\right) \delta 20.3\left(\mathrm{CH}_{2}\right), 22.1\left(\mathrm{CH}_{3}\right), 25.0\left(\mathrm{CH}_{2}\right), 26.5\left(\mathrm{CH}_{2}\right), 26.6\left(\mathrm{CH}_{2}\right), 26.9\left(\mathrm{CH}_{2}\right)$, 
$34.0(\mathrm{CH}), 36.2(\mathrm{CH}), 36.9(\mathrm{CH}), 52.2\left(2 \mathrm{xCH}_{3}\right), 131.2(\mathrm{Cq}), 132.3(\mathrm{Cq}), 135.4(\mathrm{Cq}), 137.8(\mathrm{Cq}), 167.8$ $(\mathrm{C}=\mathrm{O}), 169.0(\mathrm{C}=\mathrm{O})$.

Minor stereoisomer 6dB: ${ }^{1} \mathbf{H}$ NMR $\left(\mathrm{CDCl}_{3}, 400 \mathrm{MHz}\right) \delta 1.21\left(\mathrm{~d}, J=7.1 \mathrm{~Hz}, 3 \mathrm{H}, \mathrm{CH}_{3}\right), 1.55-2.1$ (m, $4 \mathrm{H}), 2.15(\mathrm{~m}, 2 \mathrm{H}), 2.43(\mathrm{~m}, 2 \mathrm{H}), 2.65(\mathrm{~m}, 2 \mathrm{H}), 2.85(\mathrm{~m}, 2 \mathrm{H}), 3.21(\mathrm{~m}, 1 \mathrm{H}), 3.76\left(6 \mathrm{H}, 2 \mathrm{xOCH}_{3}\right) .{ }^{13} \mathbf{C}$ NMR $\left(\mathrm{CDCl}_{3}, 100.6 \mathrm{MHz}\right) \delta 22.1\left(\mathrm{CH}_{3}\right), 23.0\left(\mathrm{CH}_{2}\right), 26.7\left(\mathrm{CH}_{2}\right), 29.7\left(\mathrm{CH}_{2}\right), 34.8\left(\mathrm{CH}_{2}\right), 37.6\left(\mathrm{CH}_{2}\right)$, $38.9(\mathrm{CH}), 39.5(\mathrm{CH}), 43.3(\mathrm{CH}), 52.3\left(2 \mathrm{xCH}_{3}\right), 129.3(\mathrm{Cq}), 129.4(\mathrm{Cq}), 136.8(\mathrm{Cq}), 137.1(\mathrm{Cq}), 168.0$ $(\mathrm{C}=\mathrm{O}), 168.5(\mathrm{C}=\mathrm{O})$.

6dA/B: HRMS (ESI/Q-TOF) m/z: [M+Na $\left.{ }^{+}\right]$calculated for $\mathrm{C}_{17} \mathrm{H}_{22} \mathrm{O}_{4} \mathrm{SNa} 345.1131$, found 345.1128. 7,10-diphenyl-1,2,3,3a,5,6,7,12a-octahydro-9H-thiopyrano[4,3,2-de][1,2,4]triazolo[1,2-a]cinnoline9,11(10H)-dione (7dA/7dB). A mixture of diene 3d (40 mg, $0.22 \mathrm{mmol}, 1$ equiv) and 4-phenyl-3H1,2,4-triazole-3,5(4H)-dione $\mathbf{D} 4(57 \mathrm{mg}, 0.33 \mathrm{mmol}, 1.5$ equiv) was stirred 1 hour, at room temperature, in dichloromethane $(1 \mathrm{~mL})$. The product was then purified by flash chromatography (heptane/ethyl acetate 8/2) and obtained as a mixture of $\mathbf{7 d A}$ and its diastereomer $\mathbf{7 d B}$ in $95: 5$ ratio (white paste, $40 \mathrm{mg}, 51 \%$ ).

Major 7dA: ${ }^{1} \mathbf{H}$ NMR $\left(\mathrm{CDCl}_{3}, 400 \mathrm{MHz}\right) \delta 1.36\left(\mathrm{~d}, J=6.5 \mathrm{~Hz}, 3 \mathrm{H}, \mathrm{CH}_{3}\right), 1.65-1.73(\mathrm{~m}, 2 \mathrm{H}), 1.81$ $1.87(\mathrm{~m}, 2 \mathrm{H}), 2.01(\mathrm{~m}, 1 \mathrm{H}), 2.73(\mathrm{~m}, 1 \mathrm{H}), 2.32(\mathrm{~m}, 1 \mathrm{H}), 2.42(\mathrm{~m}, 1 \mathrm{H}), 3.01-3.19(\mathrm{~m}, 2 \mathrm{H}), 3.57(\mathrm{~m}, 1 \mathrm{H}$, $\mathrm{SCH}), 4.37-4.40(\mathrm{~m}, 2 \mathrm{H}), 7.36(\mathrm{~m}, 1 \mathrm{H}), 7.44-7.52(\mathrm{~m}, 4 \mathrm{H}) .{ }^{13} \mathbf{C ~ N M R}\left(\mathrm{CDCl}_{3}, 100.6 \mathrm{MHz}\right) \delta 17.3$ $\left(\mathrm{CH}_{3}\right), 18.7\left(\mathrm{CH}_{2}\right), 23.9\left(\mathrm{CH}_{2}\right), 24.0\left(\mathrm{CH}_{2}\right), 27.0\left(\mathrm{CH}_{2}\right), 27.9\left(\mathrm{CH}_{2}\right), 34.0(\mathrm{CH}), 35.2(\mathrm{CH}), 36.9(\mathrm{CH})$, $51.5(\mathrm{CH}), 55.0(\mathrm{CH}), 125.7(2 \mathrm{xCH}), 128.2(\mathrm{CH}), 129.2(2 \mathrm{xCH}), 130.9(\mathrm{Cq}), 131.3(\mathrm{Cq}), 150.7$ $(\mathrm{C}=\mathrm{O}), 155.1(\mathrm{C}=\mathrm{O})$.

HRMS (ESI/Q-TOF) m/z: $\left[\mathrm{M}+\mathrm{H}^{+}\right]$calculated for $\mathrm{C}_{19} \mathrm{H}_{22} \mathrm{~N}_{3} \mathrm{O}_{2} \mathrm{~S} 356.1427$, found 356.1456.

\section{Cycloadditions of diene (3e).}

10-phenyl-1,2,3,3a,5,6, 7,12a-octahydro-9H-thiopyrano[4,3,2-de][1,2,4]triazolo[1,2-a]cinnoline-

9,11(10H)-dione (7eA) A mixture of crude diene $3 \mathbf{e}(72 \mathrm{mg}, 0.43 \mathrm{mmol}, 1$ equiv) and 4-phenyl-3H1,2,4-triazole-3,5(4H)-dione D4 (151 mg, $0.86 \mathrm{mmol}, 2$ equiv) was stirred 2 hours, at room temperature, in dichloromethane $(2 \mathrm{~mL})$. The product was then purified by flash chromatography (heptane/ethyl acetate 8/2) and 7eA was obtained as a single diastereomer (yellow paste, $22 \mathrm{mg}, 15 \%$ ). ${ }^{1} \mathbf{H}$ NMR $\left(\mathrm{CDCl}_{3}, 400 \mathrm{MHz}\right) \delta 1.70-1.78(\mathrm{~m}, 3 \mathrm{H}), 1.80-2.01(\mathrm{~m}, 3 \mathrm{H}), 2.73(\mathrm{~m}, 1 \mathrm{H}), 2.32(\mathrm{~m}, 1 \mathrm{H}), 2.75$ (m, 1H), 3.01-3.04 (m, 2H), $3.65(\mathrm{~d}, J=13.6,1 \mathrm{H}), 3.92(\mathrm{~d}, J=16.1,1 \mathrm{H}), 4.14(\mathrm{~d}, J=16.1,1 \mathrm{H}), 4.43$ $(\mathrm{d}, J=13.6,1 \mathrm{H}), 7.36(\mathrm{~m}, 1 \mathrm{H}), 7.44-7.52(\mathrm{~m}, 4 \mathrm{H}) .{ }^{13} \mathbf{C} \mathbf{~ N M R}\left(\mathrm{CDCl}_{3}, 100.6 \mathrm{MHz}\right) \delta 18.7\left(\mathrm{CH}_{2}\right), 22.7$ $\left(\mathrm{CH}_{2}\right), 23.7\left(\mathrm{CH}_{2}\right), 27.0\left(\mathrm{CH}_{2}\right), 28.2\left(\mathrm{CH}_{2}\right), 37.2(\mathrm{CH}), 45.9\left(\mathrm{CH}_{2}\right), 54.8(\mathrm{CH}), 123.3(\mathrm{CH}), 125.8$ $(2 \times \mathrm{CH}), 128.2(\mathrm{CH}), 129.3(2 \times \mathrm{CH}), 130.9(\mathrm{Cq}), 131.3(\mathrm{Cq}), 151.8(\mathrm{C}=\mathrm{O}), 153.6(\mathrm{C}=\mathrm{O})$.

HRMS (ESI/Q-TOF) m/z: [M+Na ${ }^{+}$calculated for $\mathrm{C}_{18} \mathrm{H}_{19} \mathrm{~N}_{3} \mathrm{O}_{2} \mathrm{SNa} 364.1090$, found 364.1098.

Cycloadditions of diene (3f). 
7-phenyl-1,2,3,3a,5,6, 7,7a,10a,10b-decahydrobenzo[8,1]isothiochromeno[6,7-c]furan-8,10-dione

(4fA). A mixture of diene $3 \mathbf{f}(50 \mathrm{mg}, 0.2 \mathrm{mmol}, 1.1$ equiv) and maleic anhydride D1 (20 mg, 0.2 mmol, 1 equiv) was stirred $5 \mathrm{~h}$ at $40{ }^{\circ} \mathrm{C}$ in dichloromethane $(0.3 \mathrm{~mL})$. The product $4 \mathbf{f f A}$ was then purified by flash chromatography (pentane/diethyl ether $8 / 2$ ) and obtained as single diastereomer, as a white solid, $\mathrm{mp}=142{ }^{\circ} \mathrm{C}(28 \mathrm{mg}, 41 \%)$.

${ }^{1} \mathbf{H}$ NMR $\left(\mathrm{CDCl}_{3}, 500 \mathrm{MHz}\right) \delta 1.49-1.68(\mathrm{~m}, 2 \mathrm{H}), 1.85-2.12(\mathrm{~m}, 6 \mathrm{H}), 2.48(\mathrm{~m}, 1 \mathrm{H}), 2.57(\mathrm{~m}, 1 \mathrm{H}), 2.68$ (m, 1H), $3.42(\mathrm{t}, J=8.5,1 \mathrm{H}), 3.71(\mathrm{bs}, 1 \mathrm{H}), 3.64(\mathrm{~m}, 1 \mathrm{H}), 3.84(\mathrm{dd}, J=9.0,4.2 \mathrm{~Hz}, 1 \mathrm{H}), 7.31-7.39$ (m, 3H), 7.44-7.46 (m, 2H). ${ }^{13} \mathbf{C}$ NMR $\left(\mathrm{CDCl}_{3}, 125.7 \mathrm{MHz}\right) \delta 20.4\left(\mathrm{CH}_{2}\right), 22.8\left(\mathrm{CH}_{2}\right), 25.4\left(\mathrm{CH}_{2}\right)$, $27.8\left(\mathrm{CH}_{2}\right), 27.7\left(\mathrm{CH}_{2}\right), 35.4(\mathrm{CH}), 36.6(\mathrm{CH}), 45.6(\mathrm{CH}), 46.1(\mathrm{CH}), 47.2(\mathrm{CH}), 134.3(\mathrm{Cq}), 130.2$ $(2 \mathrm{xCH}), 128.5(2 \mathrm{xCH}), 127.6(\mathrm{CH}), 136.9(\mathrm{Cq}), 135.2(\mathrm{Cq}), 171.0(\mathrm{C}=\mathrm{O}), 171.5(\mathrm{C}=\mathrm{O})$. HRMS (APCI/Q-TOF) m/z: $\left[\mathrm{M}+\mathrm{H}^{+}\right]$calculated for $\mathrm{C}_{20} \mathrm{H}_{21} \mathrm{O}_{3} \mathrm{~S}$ 341.1206, found 341.1216.

7-methyl-10-phenyl-1,2,3,3a,5,6,7,12a-octahydro-9H-thiopyrano[4,3,2-de][1,2,4]triazolo[1,2a]cinnoline-9, 11(10H)-dione (7fA). A mixture of diene $\mathbf{3 f}$ (30 mg, $0.13 \mathrm{mmol}, 1$ equiv) and 4-phenyl3H-1,2,4-triazole-3,5(4H)-dione D4 (45 mg, $0.26 \mathrm{mmol}, 2$ equiv) was stirred 1 hour, at room temperature, in dichloromethane $(0.5 \mathrm{~mL})$. The product was then purified by flash chromatography (heptane/ethyl acetate 9/1) to afford $\mathbf{7 f \mathbf { A }}$ as a single diastereomer, as a white powder (30 $\mathrm{mg}, 60 \%$ ).

${ }^{1} \mathbf{H}$ NMR $\left(\mathrm{CDCl}_{3}, 400 \mathrm{MHz}\right) \delta 1.67(\mathrm{~m}, 1 \mathrm{H}), 1.77-1.86(\mathrm{~m}, 3 \mathrm{H}), 1.88-2.01(\mathrm{~m}, 2 \mathrm{H}), 2.33(\mathrm{~m}, 1 \mathrm{H}), 2.64$ (m, 1H), $3.21(\mathrm{~m}, 1 \mathrm{H}), 3.66(\mathrm{~m}, 1 \mathrm{H}, \mathrm{SCH}), 4.41(\mathrm{~m}, 1 \mathrm{H}), 5.19(\mathrm{~s}, 1 \mathrm{H}, \mathrm{CHPh}), 7.20-7.35(\mathrm{~m}, 10 \mathrm{H}) .{ }^{13} \mathbf{C}$ NMR $\left(\mathrm{CDCl}_{3}, 100.6 \mathrm{MHz}\right) \delta 18.8\left(\mathrm{CH}_{2}\right), 23.9\left(\mathrm{CH}_{2}\right), 27.1\left(\mathrm{CH}_{2}\right), 27.0\left(\mathrm{CH}_{2}\right), 28.3\left(\mathrm{CH}_{2}\right), 37.2(\mathrm{CH})$, $55.5(\mathrm{CH}), 59.2(\mathrm{CH}), 125.6(\mathrm{CH}), 126.8(\mathrm{Cq}), 128.1(\mathrm{CH}), 128.8(2 \mathrm{xCH}), 128.9(2 \times \mathrm{CH}), 129.0(\mathrm{CH})$, $129.1(2 \times C H), 131.2(\mathrm{Cq}), 131.8(\mathrm{Cq}), 136.7(\mathrm{Cq}), 150.4(\mathrm{C}=\mathrm{O}), 154.9(\mathrm{C}=\mathrm{O})$.

HRMS (ESI/Q-TOF) m/z: [M+Na ${ }^{+}$calculated for $\mathrm{C}_{24} \mathrm{H}_{23} \mathrm{~N}_{3} \mathrm{O}_{2} \mathrm{SNa} 440.1403$, found 440.1436 .

2-(2-(methylthio)-3-phenyl-3,4,5,6a, 7,8,9,9a-octahydro-2H-thiopyrano[4,3,2-de]thiochromen-2-

yl)pyridine (10f). 2-(Methylsulfanyl)carbothioylpyridine D5 (39 mg, $0.2 \mathrm{mmol}, 1$ equiv) and boron trifluoride diethyl etherate $(0.0152 \mathrm{~mL}, 0.1 \mathrm{mmol}, 1$ equiv) were mixed in dichloromethane $(0.5 \mathrm{~mL})$. After $5 \mathrm{~min}$, diene $\mathbf{3 f}$ ( $62 \mathrm{mg}, 0.22 \mathrm{mmol}, 1.1$ equiv) was added in dichloromethane ( $0.2 \mathrm{~mL})$. Then the reaction mixture was stirred $1.5 \mathrm{~h}$ at $40^{\circ} \mathrm{C}$ in DCM. The mixture was washed with a saturated solution of $\mathrm{NaHCO}_{3}$ and the product was extracted with dichloromethane. The organic layers were then dried with $\mathrm{MgSO}_{4}$ and evaporated under vaccum. After purification by flash chromatography (heptane/ethyl acetate 9/1) the product was obtained as an inseparable mixture of two cycloadducts (ratio 10:3), as a yellow oil (54 mg, 65\%).

The regio- and stereochemical assignments of these cycloadducts have been made on the basis of the following NMR experiments: ADEQUATE: correlation between $\mathrm{CHPh}$ and $\mathbf{C q}-(\mathrm{SMe})$; selective NOESY-1D on $\mathrm{CHS}^{2}$-major: correlation with $\mathrm{SCH}_{3}$-major; weak correlation with $\mathrm{CHS}^{1}$-major; selective NOESY-1D on $\mathrm{CHS}^{2}$-minor: correlation with $\mathrm{SCH}_{3}$-minor; strong correlation with $\mathrm{CHS}^{1}$ minor; selective NOESY-1D on $\mathrm{SCH}_{3}$ : similar correlations with $\mathrm{CHS}^{2}$-major and $\mathrm{CHS}^{2}$-minor; 
NOESY-2D: correlation of SCH3 with both $\mathrm{CHPh}$ and CHPh The analysis of the NOESY spectra match with the optimized structures obtained by computational energy minimization (see SI).

Major cycloadduct 10fA: ${ }^{1} \mathrm{H}$ NMR $\left(\mathrm{CDCl}_{3}, 400 \mathrm{MHz}\right) \delta 1.80$ (s, 3H, SMe), 1.85-2.14 (m, 8H), 2.61 (m, 1H), $2.84(\mathrm{~m}, 1 \mathrm{H}), 3.70-3.74\left(\mathrm{~m}, 1 \mathrm{H}, \mathrm{CHS}^{2}\right), 3.75$ (bs, 1H, CHPh), $4.04\left(\mathrm{~m}, 1 \mathrm{H}, \mathrm{CHS}^{1}\right), 6.92-6.97$ (4H), 7.06-7.09 (m, 2H), $7.52(\mathrm{~m}, 1 \mathrm{H}), 7.67(\mathrm{~m}, 1 \mathrm{H}), 8.22$ (dd, $J=4.6,1.8,1 \mathrm{H}) .{ }^{13} \mathbf{C ~ N M R}\left(\mathrm{CDCl}_{3}\right.$, 100.6 MHz) $\delta 13.5(\mathrm{SMe}), 20.7\left(\mathrm{CH}_{2}\right), 24.9\left(\mathrm{CH}_{2}\right), 25.7\left(\mathrm{CH}_{2}\right), 27.2\left(\mathrm{SCH}_{2}\right), 32.1\left(\mathrm{CH}_{2}\right), 36.1\left(\mathrm{CHS}^{1}\right)$, $38.2\left(\mathrm{CHS}^{2}\right), 58.1(\mathrm{CHPh}), 69.3(\mathrm{Cq}-\mathrm{SMe}), 121.9(\mathrm{CH}), 122.9(\mathrm{CH}), 126.8(\mathrm{CH}), 127.2(2 \mathrm{xCH}), 130.8$ $(2 \times C H), 131.1(\mathrm{Cq}), 133.2(\mathrm{Cq}), 135.9(\mathrm{CH}), 139.5(\mathrm{Cq}), 148.1(\mathrm{CH}), 159.9(\mathrm{Cq}) . \mathbf{H R M S}(\mathbf{A P C I} / \mathbf{Q}-$ TOF) m/z: $\left[\mathrm{M}+\mathrm{H}^{+}\right]$calculated for $\mathrm{C}_{23} \mathrm{H}_{26} \mathrm{NS}_{3} 412.1222$, found 412.1188 .

Minor cycloadduct 10fB: ${ }^{1} \mathbf{H}$ NMR $\left(\mathrm{CDCl}_{3}, 400 \mathrm{MHz}\right)$, characteristic signals, $\delta 1.80$ (s, 3H, SMe), 2.46-2.52 (m, 2H), $3.24\left(\mathrm{~m}, 1 \mathrm{H}, \mathrm{CHS}^{2}\right), 3.62\left(\mathrm{~m}, 1 \mathrm{H}, \mathrm{CHS}^{1}\right), 3.91(\mathrm{bs}, 1 \mathrm{H}, \mathrm{CHPh}), 8.29$ (dd, $J=4.4$, 1.8, 1H). ${ }^{13} \mathbf{C}$ NMR $\left(\mathrm{CDCl}_{3}, 100.6 \mathrm{MHz}\right) \delta 13.5(\mathrm{SMe}), 22.7\left(\mathrm{CH}_{2}\right), 26.7,33.4,33.5,37.8,40.0$ $\left(\mathrm{CHS}^{2}\right), 42.3\left(\mathrm{CHS}^{1}\right), 59.5$ (CHPh), 67.8 (Cq-SMe), 122.0, 122.9, 126.8, 130.6, 130.9, 131.5, 133.2, 136.0, 138.9, $148.2(\mathrm{CH}), 159.7(\mathrm{Cq})$.

\section{Associated Content}

The Supporting Information is available free of charge on the ACS Publications website: NMR spectra, X-ray data, computational data.

\section{Author Information}

Corresponding Author* E-mail: gulea@unistra.fr

Present address for M. Donnard: Université de Strasbourg, CNRS, ECPM, Laboratoire d'Innovation Moléculaire et Applications LIMA, UMR 7042, 67087 Strasbourg, France

\section{ORCID}

M. Gulea: 0000-0002-2945-0078

M. Donnard: 0000-0002-9303-4634

I. Chataigner: 0000-0001-6302-7831

Author Contributions: T.C. and A.S. contributed equally to this work.

The authors declare no competing financial interest.

\section{Acknowledgements}

We thank the "Centre National de la Recherche Scientifique (CNRS)", and the University of Strasbourg (IdEX Unistra grant for T. C.) for financial support. We thank Dr. Bruno Vincent (GDS 3648) and Dr. Karolina Flidrova (PACSI, GDS 3670) for NMR analyzes, Dr. Lydia Karmazin and Corinne Bailly (GDS 3648) for X-ray analyses, Dr. Delphine Garnier (PACSI, 
GDS 3670) for HRMS measurements, and Mickael Choury (Master student) for helpful experiments. Dr. Jean Suffert is acknowledged for encouraging the achievement of this project in the laboratory. CRIANN (Saint Etienne du Rouvray, France) is acknowledged for their generous allocation of computer time.

\section{References}

1 Ilardi, E. A.; Vitaku, E.; Njardarson, J. T. J. Med. Chem. 2014, 57, 2832-2842.

2 Fringuelli, F.; Taticchi, A. in Dienes in the Diels-Alder Reaction, Wiley-Interscience, New York, 1990.

3 Nicolaou, K. C.; Snyder, S. A.; Montagnon, T.; Vassilikogiannakis, G. Angew. Chem. Int. Ed. 2002, 41, 1668-1698.

4 See, as examples: (a) Grigg, R.; Stevenson, P.; Worakun, T. Tetrahedron 1988, 44, 2033 2048. (b) Meyer, F. E.; Ang, K. H.; Steinig, A. G.; de Meijere, A. Synlett 1994, 191-193. (c) Ang, K. H.; Bräse, S.; Steinig, A. G.; Meyer, F. E.; Liebaria, A.; Voigt, K.; de Meijere, A. Tetrahedron, 1996, 52, 11503-11528. (d) Lautens, M.; Smith, N. D.; Ostrovsky, D. J. Org. Chem. 1997, 62, 8970-8971. (e) Trost, B. M.; Tanoury, G. J.; Lautens, M.; Chan, C.; Macpherson, T. D. J. Am. Chem. Soc. 1994, 116, 4255-4267. (f) Campbell, C. D.; Greenaway, R. L.; Holton, O. T.; Walker, P. R.; Chapman, H. A. Russell, C. A.; Carr, G. Thomson, A. L.; Anderson, E. A. Chem. Eur. J. 2015, 21, 12627-12639. (g) Greenaway, R. L.; Campbell, C. D.; Chapman, H. A.; Anderson, E. A. Adv. Synth. Catal. 2012, 354, 3187-3194.

5 See, as examples: (a) Capella, L.; Montevecchi, P. C.; Navacchia, M. L. J. Org. Chem. 1995, 60, 7424-7432. (b) Caddick, S.; Shering, C. L.; Wadman, S. N. J. Chem. Soc., Chem. Commun. 1997, 171-172. (c) Journet, M.; Rouillard, A.; Cai, D.; Larsen, R. D. J. Org. Chem. 1997, 62, 8630-8631. (d) Crich, D.; Fortt, S. M. Tetrahedron Lett. 1987, 28, 2895 2898.

6 Gaoni, Y.; Sadeh, S. J. Org. Chem. 1980, 45, 870-881.

7 Lovering, F.; Bikker, J.; Humblet, C. J. Med. Chem. 2009, 52, 6752-6756.

8 Tietze, L. F.; Modi, A. Eur. J. Org. Chem. 2000, 1959-1964.

9 Grigg, R.; Sridharan,; V. Stevenson,; P. Sukirthalingam,; S. Worakum, T. Tetrahedron. 1990, 46, 4003-4018.

10 (a) Sha, C.-K.; Zhan, Z.-P.; Wang, F.-S. Org. Lett. 2000, 2, 2011-2013. (b) Zhan, Z.-P.; Lang, K. Org. Biomol. Chem. 2005, 3, 727-728.

11 For a recent review on the stereoselective synthesis of 1,3-dienes, see: De Paolis, M.; Chataigner, I.; Maddaluno, J. Top. Curr. Chem. (2012) 327: 87-146; Springer-Verlag Berlin Heidelberg. 
12 For some recent reviews in this topic, see: (a) Vlaar, T.; Ruijter, E.; Orru, R. V. A. $A d v$. Synth. Catal. 2011, 353, 809-841. (b) Ohno, H. Asian J. Org. Chem. 2013, 2, 18-28. (c) Düfert, A.; Werz, D. B. Chem. Eur. J. 2016, 22, 16718-16732. (d) Blouin, S.; Blond, G.; Donnard, M.; Gulea, M.; Suffert J. Synthesis 2017, 49, 1767-1784.

(a) Castanheiro, T.; Donnard, M.; Gulea, M.; Suffert, J. Org. Lett. 2014, 16, 3060. (b) Castanheiro, T.; Suffert, J.; Donnard, M.; Gulea, M. Phosphorus, Sulfur Silicon Relat. Elem. 2017, 192, 162. (c) Castanheiro, T.; Schoenfelder, A.; Suffert, J.; Donnard, M.; Gulea, M. C. R. Chim. 2017, 20, 624-633. (d) Donnard, M.; Castanheiro, T.; Gulea, M. In Targets in Heterocyclic Systems; Vol. 21 (Eds. Attanasi, O. A.; Spinelli, D.), Ed. Italian Society of Chemistry, 2017, pp 254-276.

14 Couty, S.; Liégault, B.; Meyer, C.; Cossy, J. Org. Lett. 2004, 6, 2511-2514.

15 Kundu, N. G.; Nandi, B. Tetrahedron, 2001, 57, 5885-5895.

16 See for a study of this type of DA reaction: Cayzer, T. N.; Lilly, M. J.; Williamson, R. M.; Paddon-Row, M. N.; Sherburn, M. S. Org. Biomol. Chem., 2005, 3, 1302-1307.

17 For HDA reactions with dithioester D6, see: Bastin, R.; Albadri, H.; Gaumont, A.-C.; Gulea, M. Org. Lett. 2006, 8, 1033-1036.

18 See for instance: (a) Minenkov, Y.; Singstad, A.; Occhipinti, G.; Jensen V. R. Dalton Trans. 2012, 41, 5526-5541. (b) Hamzehloueian, Y.; Sarrafi, M.; Aghaei Z. RSC Adv. 2015, 5, 76368-76376. (c) Boz, E.; Tüzün N. S. Dalton Trans. 2016, 45, 5752-5764. 